\title{
El régimen de las competencias y de los límites de los distritos en las legislaciones nacional y autonómicas ${ }^{1}$
}

\author{
Dionisio Fernández de Gatta Sánchez \\ Profesor Titular de Derecho Administrativo. Universidad de Salamanca
}

Sumario: I. ASPECTOS GENERALES: EL SIGNIFICADO DEL PRINCIPIO DE DESCONCENTRACIÓN Y SUS LÍMITES COMO MARCO.-II. EL RÉGIMEN JURÍDICO GENERAL DE LOS DISTRITOS: A) Una cuestión previa: la especial adecuación de la desconcentración territorial en relación con la situación urbana y poblacional de España. B) Algunos antecedentes normativos. C) La regulación jurídica general de los Distritos. 1) Aspectos generales. 2) El régimen jurídico vigente. - III. COMPETENCIAS Y LÍMITES DE LOS DISTRITOS: A) Referencias generales. B) Competencias y límites de los Distritos en la Legislación Básica. C) Competencias y límites de los Distritos en la Legislación autonómica: 1) Comunidad Autónoma de Andalucía. 2) Comunidad Autónoma de Aragón. 3) Comunidad Autónoma de Asturias. 4) Comunidad Autónoma de las Islas Baleares. 5) Comunidad Autónoma de Canarias. 6) Comunidad Autónoma de Cantabria. 7) Comunidad Autónoma de Castilla-La Mancha. 8) Comunidad Autónoma de Castilla y León. 9) Comunidad Autónoma de Cataluña. 10) Comunidad Autónoma de Extremadura. 11) Comunidad Autónoma de Galicia. 12) Comunidad Autónoma de Madrid. 13) Comunidad Autónoma de Murcia. 14) Comunidad Autónoma de Navarra. 15) Comunidad Autónoma de La Rioja. 16) Comunidad Autónoma del País Vasco. 17) Comunidad Autónoma Valenciana. 18) Ciudades Autónomas de Ceuta y Melilla.

\section{ASPECTOS GENERALES: EL SIGNIFICADO DEL PRINCIPIO DE DESCONCENTRACIÓN Y SUS LÍMITES COMO MARCO}

El principio de desconcentración continúa actualmente siendo uno de los menos estudiados del Ordenamiento Jurídico, a pesar de su mención en la Constitución Española de 1978; y menos aún estudiada es la aplicación del mismo en

\footnotetext{
1 El presente trabajo constituye la Ponencia presentada en las VI Jornadas de Coordinación Territorial «Madrid Distrito Abierto», organizadas por el Área de Coordinación Territorial del Excmo. Ayuntamiento de Madrid, y celebradas en Madrid los días 26 y 27 de noviembre de 2007. Agradezco a Lucía BRUZIELA CASTILLO (Directora General de Coordinación Territorial del Ayuntamiento de Madrid), Cayetano PRIETO ROMERO (Director General de Organización y Régimen Jurídico del Ayuntamiento de Madrid) y Alfredo GALÁN GALÁn (Profesor Titular de Derecho Administrativo de la Universidad de Barcelona) la invitación para participar en estas interesantes y consolidadas Jornadas; así como a Tomás QUINTANA LóPEZ (Catedrático de Derecho Administrativo de la Universidad de León).
} 
la Administración Local ${ }^{2}$. Ciertamente, se ha prestado alguna atención, en textos clásicos, a la desconcentración administrativa en general, más al proceso de creación de órganos para la gestión desconcentrada de competencias que a la propia técnica operativa entre órganos ya creados, y mucha menos al uso de esta técnica en la Administración Local; situación que se explicaba en parte por el carácter limitado y estricto de la regulación preconstitucional ${ }^{3}$, aunque la misma no cambió mucho posteriormente ${ }^{4}$. En el ámbito de la Administración Local, y en particular de la Municipal, el estudio y el desarrollo ha sido mayor al preverse tal técnica desconcentradora en la Legislación Básica nacional y en las normas regionales en la materia ${ }^{5}$.

2 Tomás QUINTANA LóPEZ ponía de manifiesto esta situación en su interesante trabajo «La desconcentración en la organización de los Municipios», Documentación Administrativa, n. ${ }^{2}$ 228/1991, monográfico sobre «La Organización Municipal», págs. 145-165. Años después, en 2007, Alfredo GALÁN GALÁN se expresa con palabras parecidas en su importante y amplio trabajo «Valoración general. La desconcentración territorial en los Municipios: los Distritos», en C. PRIETO Romero y A. GAlán GALÁn (Dir.), y otros, «Los Distritos: Gobierno de Proximidad», Ed. Excmo. Ayuntamiento de Madrid y Ed. Thomson-Civitas, Cizur Menor (Navarra), 2007, págs. 17-147, que constituye ya una obra de referencia en la materia, al llenar el vacío existente sobre la cuestión respecto a la Administración Municipal. Además, debemos resaltar que en la misma obra se incluye el trabajo de CORRALES GuILLÉN, J. C., «La desconcentración como principio jurídico y técnica de organización», págs. 151-188, que constituye un estudio detallado sobre este principio en general. [Agradezco a C. PRIETO ROMERo y A. GALÁN GALÁn el envío, antes de celebrarse las Jornadas, del texto original no publicado de esta obra].

3 Entre los estudios clásicos sobre la desconcentración, hemos de seguir mencionando los trabajos de DE LA VAllina Velarde, J. L., «La desconcentración administrativa», Revista de Administración Pública, n. ${ }^{\circ}$ 35/1961, CARrasco CANALS, C., «Un criterio organizativo polémico: la desconcentración», RAP, n. ${ }^{\circ}$ 75/1974, y los Manuales y Tratados de Derecho Administrativo de la época, bien conocidos. En el ámbito local, continúa siendo imprescindible la obra de ORTIZ DíAZ, J., «La desconcentración territorial en la Administración Local», Ed. Instituto de Estudios de Administración Local, Madrid, 1972.

Asimismo, por su carácter detallado y ámbito general, véase CORRALES GuILLÉN, J. C., «La desconcentración como principio jurídico y técnica de organización», citado, págs. 151-188.

4 Después de publicada la Constitución Española, véanse ARIÑo OrTIZ, G., «Principios de descentralización y desconcentración», Documentación Administrativa, n. ${ }^{\circ}$ 214/1988; GALLEGO ANABITARTE, A., «Transferencia y descentralización; delegación y desconcentración; mandato y gestión o encomienda», $R A P, \mathrm{n} .^{\circ}$ 122/1990; ÁlVAREZ RICO, M., «Principios constitucionales de organización de las Administraciones Públicas», Ed. Dykinson, Madrid, 1997; LAVILla RuBIRA, J. J., «Desconcentración (Derecho Administrativo)», Enciclopedia Jurídica Básica, Tomo II, Ed. Civitas, Madrid, 1995, y MESEGUER YEBRA, J., «La competencia administrativa y sus modulaciones. Manual para la desconcentración, delegación, avocación, encomienda de gestión, delegación de firma y suplencia», Ed. Bosch, Barcelona, 2005, y «La desconcentración como técnica de modulación competencial interorgánica. Régimen jurídico y aplicación práctica: virtudes y defectos», Revista Jurídica de Castilla-La Mancha, n. ${ }^{\circ}$ 38/2005, págs. 133-153. En sentido general, la Revista Documentación Administrativa dedicó su n. ${ }^{\circ}$ 214/1988 a los principios organizativos de la Administración en la Constitución Española, reflejando claramente la situación reseñada.

5 En este ámbito son imprescindibles las obras de A. Galán Galán y de C. Prieto Romero que se citan en este trabajo, en particular el libro mencionado sobre «Los Distritos: Gobierno de Proximidad».

Alguna atención también se ha prestado al estudio de la desconcentración desde el punto de vista urbanístico y territorial; vid. los trabajos de la antigua COPLACO sobre Madrid y MALLARACH ISERN, J., y VILAGRASA IBARZ, J., «Los procesos de desconcentración urbana en las ciudades medias españolas», Ería-Revista Cuatrimestral de Geografía, n. ${ }^{\circ}$ 57/2002, págs. 57-70. En este sentido, también es interesante el trabajo de GALÁN GALÁn, A., y TOSCANO GIL, F., «Las tres dimensiones de la gran ciudad», en TronCOSO REIGADA, A. (Dir.), y otros, «Comentarios a la Ley de Capitalidad y de Régimen Especial de Madrid. Ley 22/2006, de 4 de julio», Ed. Thomson-Aranzadi, Cizur Menor (Navarra), 2007. 
EL RÉGIMEN DE LAS COMPETENCIAS Y DE LOS LÍMITES DE LOS DISTRITOS...

No obstante lo anterior, debe resaltarse la importancia del principio de desconcentración en una sociedad tan compleja como la actual, en la que, a su vez, las Administraciones Públicas constituyen quizás el sistema organizativo más complejo del Poder Público.

La desconcentración, como es bien sabido, supone una reordenación normativa de las competencias mediante la cual se transfiere la titularidad y el ejercicio de competencias administrativas, en el ámbito de una misma Administración Pública, de los órganos superiores a otros de nivel inferior, de manera permanente y como propia de los órganos que la reciben (STS de 12 de marzo de 1990, AR. 2522, que, además, la distingue de la técnica de la descentralización); proceso que puede tener connotaciones territoriales (la denominada desconcentración territorial; que se refleja en los Distritos, como veremos) o no (la llamada desconcentración funcional, que es visible, p. ej., en la relación entre un Ministro y un Director General, en el Ministerio correspondiente); siendo el fundamento último de esta técnica la eficacia en la acción administrativa, al tener por finalidad acercar la misma a los ciudadanos, colocándose así la Administración más cerca de los problemas reales de los mismos, y de sus soluciones (SsTS de 12 de mayo de 1990, AR. 6979, y de 4 de enero de 1991, AR. 501, y ATS de 27 de marzo de 1992, AR. 2808); descongestionando de trabajo los niveles superiores de la organización y agilizando así la actividad administrativa. Además, también es útil para favorecer la participación ciudadana en la acción de las Administraciones Públicas. En este sentido, con mucha claridad se expresa la STS de 16 de enero de 1990 (AR. 7477), referida al Ayuntamiento de Barcelona, al señalar que tal técnica «...no significa la aparición de entes menores y tan sólo constituye una técnica organizativa instrumental con la finalidad explícita de facilitar la participación ciudadana en la gestión de los asuntos locales y mejorar éstos. En definitiva, los distritos son dependientes de la Corporación con una base territorial y, por tanto, órganos de la Administración que cumplen funciones ejecutivas...».

Debido a la visible trascendencia de esta técnica en los Estados democráticos modernos, el principio de desconcentración se recoge en el art. 103-CE, como principio de organización aplicable a todas las Administraciones Públicas (tal como reconocen la STC 85/1983, de 25 de octubre, y la STS de 14 de mayo de 1998, AR. 4801), y se menciona con carácter general en las Leyes Administrativas más importantes, tanto nacionales (así, p. ej., en el art. 12 de la Ley de Régimen Jurídico de las Administraciones Públicas y del Procedimiento Administrativo Común de 1992 o en el art. 3 de la Ley de Organización y Funcionamiento de la Administración General del Estado de 1997), como autonómicas (por todas, Ley del Gobierno y Administración de la Comunidad de Castilla y León de 2001); así como, según veremos, en la Legislación relativa a la Administración Local, y más en concreto a la Municipal.

En relación a las competencias que, con carácter general, pueden ser desconcentradas, y sin perjuicio de lo que se señalará más adelante respecto al ámbito municipal, el Ordenamiento Jurídico no establece directamente disposi- 
ción alguna, siendo posible pues llevar a cabo estos procesos de forma amplia en relación con las competencias del órgano que desconcentra, si bien esta amplitud tiene al menos dos límites de carácter general: por un lado, la necesidad de que el proceso de desconcentración cumpla su finalidad esencial (es decir, acercar la gestión y la acción administrativa a los ciudadanos, descongestionando los niveles administrativos superiores, y redundando así en una mayor eficacia administrativa) $)^{6}$, y, por otro lado, que la desconcentración competencialmente sea de tal magnitud que desdibuje y haga irreconocible la figura del órgano que desconcentra (en este sentido, la STS de 12 de mayo de 1990, AR. 6979, habla de pérdida de competencias de ése órgano), es decir, es necesario que este último mantenga su sentido previsto en el Ordenamiento y el protagonismo en la acción administrativa concreta, ya que de otra forma se estaría produciendo materialmente una sustitución orgánica, no prevista jurídicamente.

\section{EL RÉGIMEN JURÍDICO GENERAL DE LOS DISTRITOS}

\section{A) Una cuestión previa: la especial adecuación de la desconcentración territorial en relación con la situación urbana y poblacional de España.}

Tal como hemos señalado, el principio de desconcentración supone una técnica que trata de hacer más efectiva y ágil la acción administrativa, al descargar la misma de los niveles superiores de la organización administrativa para entregarla a los niveles más cercanos al ciudadano; proceso que se justifica, pues, en la adecuada gestión administrativa. No obstante, este proceso es especialmente útil y adecuado cuando tiene connotaciones territoriales, en especial, ya en el ámbito municipal, en los supuestos de las grandes y complejas aglomeraciones urbanas, en las que la aplicación de este principio acerca la Administración Municipal a los ciudadanos a un nivel territorial inferior, más cercano a los problemas reales; con lo que se plantean métodos más adecuados de la gestión local.

Según datos oficiales del Instituto Nacional de Estadística, referidos a 1 de enero de 2007, España se caracteriza territorialmente por tener un gran número (seguramente excesivo) de Municipios, en particular la gran mayoría muy pequeños; número que, salvo la importante supresión de los mismos llevada a cabo entre 1960 y 1981, no ha dejado de aumentar hasta llegar a los actuales 8.111 Municipios (de los que 2.248 corresponden a la Comunidad de Castilla y León). Además de estos datos numéricos, deben tenerse en cuenta los relativos a la población española y a su distribución territorial: la gran mayoría de la

\footnotetext{
6 Corrales Guillén, J. C., trabajo citado, págs. 186-187, y GALÁn Galán, A., «Valoración general. La desconcentración territorial en los Municipios: los Distritos», en C. PRIETO ROMERO y A. GALÁN GALÁN (Dir.), y otros, «Los Distritos: Gobierno de Proximidad», obra citada, págs. 86-88.
} 
población española (casi 45 millones de habitantes) se concentra en las ciudades de más de 100.000 habitantes, que son 59 sobre el total de Municipios (53 ciudades cuentan con más de 100.000 habitantes y únicamente 6 ciudades con más 500.000 habitantes: Madrid, Barcelona, Sevilla, Valencia, Málaga, Zarago$\mathrm{za}$, ciudades de la costa mediterránea, algunas «islas poblacionales interiores» y otras de las costas gallegas y del norte). Es decir, España es esencialmente una sociedad muy urbana radicada en un territorio mayoritariamente rural; teniendo problemas de dispersión de la población en Municipios muy pequeños y de una fuerte concentración en muy pocos Municipios de gran tamaño ${ }^{7}$.

En este sentido, aunque con otros datos urbanos y de población, justamente en los Municipios españoles de mayor población fue en los que la desconcentración territorial (con algún matiz) se empezó a diseñar y a utilizar años atrás.

\section{B) Algunos antecedentes normativos}

En nuestra rica historia municipal ${ }^{8}$ la regulación de la desconcentración territorial prácticamente no es visible hasta bien entrado el siglo XX, y esto aún

\footnotetext{
7 Respecto a la problemática estructura urbana y poblacional de España, véanse CALONGE VALÁZQUEZ, A., «La planta municipal y las Entidades Locales Menores en Castilla y León», Revista de Estudios de la Administración Local, n. ${ }^{\circ}$ 285/2001; CANALES ALIENDE, J. M., «Reflexiones sobre la situación y la problemática actual del gobierno y de la administración de las grandes ciudades españolas», Revista de Estudios de la Administración Local y Autonómica , n. 265/1995; FERNÁNDEZ DE GATTA SÁNCHEZ, D., «Los problemas de la estructura municipal de Castilla y León: instrumentos y soluciones de la nueva Ley de Régimen Local», El Consultor, n. ${ }^{\circ}$ 19/1999, «La estructura municipal de Castilla y León: Incidencia de la Legislación sobre Régimen Local, Urbanismo y Ordenación del Territorio», Revista de Estudios de la Administración Local, n. ${ }^{\circ}$ 291/2003, en Homenaje al Prof. Dr. D. Sebastián MARTín-RETORTILlo BAQUER, «Las Mancomunidades Municipales en Castilla y León: evolución, régimen vigente y perspectivas futuras», REALA, n. ${ }^{\circ} 296-297$, septiembre de 2004-abril de 2005, y «El Acuerdo de Pacto Local de Castilla y León de 2005: Un instrumento para la consolidación de las Administraciones Locales de la Comunidad», X Congreso de Economía de Castilla y León [Valladolid, 23 y 24 de noviembre de 2006], Comunicaciones, Vol. I, Ed. Consejería de Economía y Empleo (JCyL), Valladolid, 2006; Mozo AMO, J., «El Municipalismo. Presente y futuro del pequeño Municipio. Especial referencia a Castilla y León», Revista de Estudios Locales, n. ${ }^{\circ}$ 60/2002; RAMíREZ EsTÉVEZ, G., «Estrategias poblacionales para Castilla y León», Ed. Consejería de Economía y Hacienda (JCyL), Valladolid, 1999; RoDRÍGUEZ ÁlvareZ, J. M., «Las Asociaciones de Entidades Locales en España», Ed. INAP-BOE, Madrid, 2002, y «La Política sobre Grandes Ciudades y Áreas Metropolitanas en España o el temor a la diversidad», Gestión y Análisis de Políticas Públicas, n. ํ2 24/2002.
}

8 Sobre la historia municipal y provincial española véase la interesante obra de ORDUÑA REBOLLO, E., «Municipios y Provincias. Historia de la organización territorial española», Ed. FEMP-INAP-CEPC, Madrid, 2003. También, vid. VARIOS AUTORES, «El Municipio Constitucional» [II Seminario de Historia de la Administración Local, 2002], Ed. INAP-MAP, Madrid, 2003. Sobre los Distritos, en concreto, véase VILLAR RoMERO, J. M. ${ }^{\text {., }, ~ « D i s t r i t o », ~ N u e v a ~ E n c i c l o p e d i a ~ J u r i ́ d i c a ~ S e i x, ~ T o m o ~ V I I, ~ E d . ~ S e i x, ~ B a r c e l o n a, ~} 1974$.

Respecto a la evolución histórica del régimen de Madrid, vid. FERNÁNDEZ-MIRANDA FERNÁNDEZ-MIRANDA, J., «Evolución histórica del régimen especial de Madrid», en PAREJO AlfONSO, L., BRAVO RivERA, J., y Prieto Romero, C. (Coords.), y otros, «Estudios sobre la Ley de Capitalidad y de Régimen Especial de Madrid», Ed. Bosch-Excmo. Ayuntamiento de Madrid, Barcelona, 2006, págs. 37-95, y respecto a la ciudad de Barcelona, ver JiMÉNEZ ASENSIO, R., y MALlo GóMEZ, M., «La organización territorial en Distritos del Municipio de Barcelona», en C. PRIETo Romero y A. GALÁN GALÁn (Dir.), y otros, «Los Distritos: Gobierno de Proximidad», obra citada, págs. 277-334, y JiMÉNEZ ASENSIO, R., «El régimen especial del Municipio de Barcelona: evolución y contenido actual», en TRONCOSO REIGADA, A. (Dir.), y otros, «Comentarios a la Ley 
de forma incipiente, y con connotaciones urbanísticas y poblacionales claras. En este punto, pueden mencionarse las Leyes de 1944 y 1946 que permitieron la aplicación de un régimen urbanístico especial a Madrid, Bilbao y Valencia; cuestión que respecto a Barcelona y su comarca realizó una Ley de 1953. Más tarde, la Legislación Local de 1955 únicamente admitirá una cierta desconcentración funcional en la prestación de servicios o en la existencia de Alcaldes de Barrio (con las funciones que quisieran delegarles los Alcaldes) ${ }^{9}$. Posteriormente, las ya apreciables dimensiones urbanas de Madrid y de Barcelona, así como su proceso de rápido crecimiento, provocará que, mediante una modificación de la Ley de Régimen Local citada, se aprobaran para ambas ciudades Leyes especiales en 1963 para Madrid (Decreto 1674/1963, de 11 de julio, BOE del 18, modificado en 1970) y, antes, en 1960 para Barcelona (Decreto 1166/1960, de 23 de mayo, BOE del 24 de junio, modificado en 1974), en las que se articulan las Juntas Municipales de Distrito, que agrupaban barrios, para colaborar tímidamente en la Administración municipal y en la gestión de algunos servicios (regímenes aplicables, según la Disp. Ad. 6. ${ }^{\mathrm{a}}$-LBRL, hasta la aprobación de la Ley especial prevista para Madrid, en el primer caso, y en lo que no se opongan a la propia Ley de Bases, en ambos supuestos; si bien es posible actualizar dichos regímenes mediante Ley autonómica).

\section{C) La regulación jurídica general de los Distritos ${ }^{10}$}

\section{1) Aspectos generales}

Como cuestión inicial, y es sabido, debe resaltarse que el régimen uniforme y homogéneo de la organización administrativa local ${ }^{11}$, que es bien visible en la

\footnotetext{
de Capitalidad y de Régimen Especial de Madrid. Ley 22/2006, de 4 de julio», Ed. Thomson-Aranzadi, Cizur Menor (Navarra), 2007, págs. 875-912.

9 Quintana LóPEZ, T., «La desconcentración en la organización de los Municipios», trabajo citado, págs. 147-148.

10 Este régimen jurídico es estudiado con detalle por GALÁN GALÁN, A., «Valoración general. La desconcentración territorial en los Municipios: los Distritos», obra citada.

11 En general, sobre el régimen jurídico de la Administración Local, véanse RIVERO YSERN, J. L., «Manual de Derecho Local», Ed. Thomson-Civitas, Madrid, 2004; SosA WAGNER, F., «Manual de Derecho Local», 9. ${ }^{a}$ ed., Ed. Thomson-Civitas, Cizur Menor (Navarra), 2005; FERnÁndeZ DE GATTA SÁnCHEZ, D., y PÉREZ AlEnCART, A., «Manual del Alcalde», (1. a ed. 1998) 2. ${ }^{\mathrm{a}}$ ed. ampliada, Ed. Diputación de Valladolid y Universidad de Salamanca, Valladolid, 2004 http://www.diputaciondevalladolid.es/am/manual_alcalde.shtml?id boletin=471\&idseccion=2341\&idarticulo=17714; DOMINGO ZABALLOS, M. J. (Coord.), y otros, «Comentarios a la Ley Básica de Régimen Local», 2. ${ }^{a}$ ed., Ed. Thomson-Civitas, Madrid, 2005; BuENAVENTURA, R. (Dir.), y otros, «Guía de la Política Pública Local», 2. ${ }^{\text {e }}$ d., Ed. Consultores de Administraciones Públicas, Madrid, 2003, y SAlaZAR BENíTEZ, O., «El sistema de gobierno municipal», Ed. Centro de Estudios Políticos y Constitucionales, Madrid, 2007.
}

Sobre la autonomía local, en general y con referencias a la organización, vid. GALÁN GALÁN, A., «La potestad normativa autónoma local», Ed. Atelier, Barcelona, 2001, y «El Reglamento Orgánico Local», Ed. INAPMAP, Madrid, 2004. En relación a este principio en la actualidad, ver CARRO FERNÁNDEZ-VALMAYOR, J. L., «Una nueva reflexión sobre la autonomía municipal», II Congreso de la Asociación Española de Profesores 
EL RÉGIMEN DE LAS COMPETENCIAS Y DE LOS LÍMITES DE LOS DISTRITOS...

Administración española, se plantea en la Revolución Francesa al rechazarse el carácter privilegiado de los Municipios regidos por normas particulares del Antiguo Régimen, en base al principio de igualdad; suprimiéndose por ello todos los privilegios territoriales y personales en 1789. Se establece, así, la unidad de la organización municipal, aplicando las mismas normas a las grandes ciudades y a los pequeños pueblos (salvo a la capital), y además se prevé la creación de un Municipio por cada núcleo de población. Ambas ideas se asumieron en España por la Constitución de 1812, al establecer que «...se pondrá Ayuntamiento en los pueblos que no lo tengan, y en que convenga que lo haya, no pudiendo dejar de hacerlo en los que por sí o con su comarca lleguen mil almas...». Es más, a partir de este momento, las previsiones de población se relajaron mucho más. Posteriormente, dependiendo de la época histórica, estas mismas ideas se mantienen en mayor o en menor medida, hasta llegar al siglo XX en que la generalización del régimen municipal se comienza a poner en entredicho debido a las incongruencias que se producen entre la homogeneidad jurídica y la heterogeneidad sustancial de los Municipios.

La Ley 7/985, de 2 de abril, de Bases de Régimen Local (BOE del 3), en su versión original, incluye escasas novedades organizativas, asumiendo democráticamente el modelo histórico, que apenas altera; y que se articula sobre el reconocimiento de la autonomía local y la determinación por el Estado de las bases del régimen jurídico de la Administración Local, aceptando así la uniformidad y generalización del régimen local, junto a las diversas opciones en la organización municipal a establecer por las Comunidades Autónomas y los propios Municipios; opciones que determinan, no obstante, una apreciable diversidad en la estructura local (como se reflejó en los arts. 5 y 20, y así se entendió por la STC 214/1989, de 21 de diciembre).

En este marco real, y sobre la base del reconocimiento del principio de desconcentración que realiza el art. 103-1. ${ }^{\circ}, \mathrm{CE}^{12}$, y de la distribución de competen-

\footnotetext{
de Derecho Administrativo, Santander, 2 de febrero de 2007 (doc. original); VARIOS AUTORES, «El Municipio Constitucional», citado; VelASCO CABALLERO, F. «Autonomía municipal», II Congreso de la Asociación Española de Profesores de Derecho Administrativo, Santander, 2 de febrero de 2007 (doc. original), y FuENTETAJA PASTOR, J. Á., «Autonomía Local y Legislación Básica», en PARADA VÁZqueZ, R., y FuENTETAJA PASTOR, Á.. (Dirs.), y otros, «Reforma y retos de la Administración Local», Ed. Fundación Caja Rural de Toledo-Maat Gknowledge-Ed. Marcial Pons, Madrid, 2007.
}

Sobre la situación actual de la Administración Local y sus preocupantes perspectivas futuras, véanse el agudo trabajo, como siempre, de PARADA VÁZQUEZ, R., «La segunda descentralización: del Estado autonómico al municipal» (también publicado como libro por Ed. Thomson-Civitas, Cizur Menor-Navarra, 2007), y PAREJO ALFONSO, L., «Las perspectivas del nuevo régimen local», ambos en PARADA VÁZQUEZ, R., y FUENTETAJA PASTOR, Á. (Dirs.), y otros, «Reforma y retos de la Administración Local», obra citada.

Respecto a las normas locales, vid. BOLETín OfiCIAL DEL EsTADO, «Régimen Local», 9. a ed., Madrid, 2007; Sosa Wagner, F., «Código de Administración Local», Ed. Thomson-Aranzadi, Cizur Menor (Navarra), 2007, y Carbonell Porras, E., Rebollo Puig, M., y LóPez Benítez, M., «Código de Legislación de Régimen Local», 5. ${ }^{\text {a } e d ., ~ E d . ~ T h o m s o n-C i v i t a s, ~ M a d r i d, ~} 2004$.

12 CorRales GuilléN, J. C., «La desconcentración como principio jurídico y técnica de organización», citado, y Galán Galán, A., García Arán, G., y Grande PÉrez, A., «El art. 103-1. e la Constitución en 
cias establecida por el art. $149-1 .^{\circ}, 18 .^{\text {a }}$ de la misma, el texto original de la Ley de Bases del Régimen Local reafirma el principio de desconcentración en su art. 6-1. ${ }^{\circ}$, e introduce la desconcentración territorial en el ámbito municipal al prever en su art. 24, como cauce de participación, la posibilidad de que los Municipios establezcan «órganos territoriales de gestión desconcentrada, con la organización, funciones y competencias que cada Ayuntamiento les confiera, atendiendo a las características del asentamiento de la población en el término municipal, sin perjuicio de la unidad de gobierno y gestión del Municipio». Obviamente, esta previsión del proceso de desconcentración es parcial, pues la LBRL se refiere al mismo exclusivamente como técnica de participación de los vecinos, lo cual es un primer límite; aunque con carácter más general podrían crearse órganos desconcentrados con el carácter de órganos complementarios, sobre la base del art. 20 (y según la STC 214/1989, de 21 de diciembre, F.J. n. 6). Además, el mismo art. 24 se refiere a otro límite directo de carácter urbanístico-poblacional, cual es que en tal proceso ha de atenderse a las características del asentamiento de la población en el término municipal. Finalmente, el mismo precepto impide que el proceso afecte a la unidad de gobierno y gestión del Municipio, pues los órganos necesarios de su organización, según el art. 20, son los que representan el principio democrático directamente, por lo que a ellos encomienda el Ordenamiento tales tareas (cuestión que se reafirma en el art. 69-LBRL, como veremos). Seguidamente, la información y la participación ciudadanas son reguladas en los arts. 69 a 72-LBRL, reiterando la posibilidad de las Corporaciones Locales de facilitar, entre otras cuestiones, la participación ciudadana, mediante el ejercicio de la potestad de autoorganización (relativa a las formas, medios y procedimientos; posibilitando pues la creación de Órganos desconcentrados), si bien con un límite expreso: no menoscabar las facultades de decisión que corresponden a los Órganos representativos; por su carácter democrático principal en esta Administración.

Por su parte, el Texto Refundido de Régimen Local (Real Decreto Legislativo 781/1986, de 18 de abril, BOE de 22 y 23 de abril), prevé la posibilidad, de acuerdo con el Reglamento Orgánico del Municipio, de que los Alcaldes nombren un representante personal en los poblados y barriadas separados de casco urbano, así como en las ciudades en que el desenvolvimiento de los servicios así lo aconseje (art. 20; precepto que no tiene carácter básico, ex Disp. Final 7. a del mismo). Además, y con el carácter de norma supletoria, el Reglamento de Población y Demarcación Territorial (Real Decreto 1690/1986, de 11 de julio, BOE de 14 de agosto) reafirma la competencia del Ayuntamiento para dividir el término municipal en Distritos y otras divisiones.

\footnotetext{
la jurisprudencia», Documentación Administrativa, n. ${ }^{\circ}$ 214/1988, págs. 235-261. Respecto al ámbito municipal, ver MARTíN PÉREZ, P. A., «Sistemas de descentralización y desconcentración en las Leyes municipales españolas», Actualidad Administrativa, Tomo 2/1990, y RoDríGUEZ ÁlVAREZ, J. M., «Las Juntas de Distrito en las grandes ciudades españolas. Un estudio comparado de su organización y de su regulación positiva», Actualidad Administrativa, Tomo 2/1996.
} 
EL RÉGIMEN DE LAS COMPETENCIAS Y DE LOS LÍMITES DE LOS DISTRITOS...

Más concreta, pero de nivel menor dada su naturaleza jurídica supletoria según la distribución de competencias en la materia, es la regulación de los órganos desconcentrados en el Reglamento de Organización, Funcionamiento y Régimen Jurídico de las Entidades Locales (aprobado por Real Decreto 2568/1986, de 28 de noviembre, BOE de 22 de diciembre) ${ }^{13}$; que, como órganos complementarios, se prevén en el art. 119 y se regulan en los arts. 128 a 133, si bien el Pleno puede establecer otros distintos (art. 132). En primer término, el ROF prevé que el propio Pleno Municipal podrá crear Juntas Municipales de Distrito, como órganos territoriales de gestión desconcentrada con la finalidad de mejorar la gestión de los asuntos de competencia municipal y facilitar la participación ciudadana. Para su regulación, se prevé un Reglamento, que es parte integrante del Reglamento Orgánico municipal, en el que se deben precisar las funciones administrativas que, «en relación a las competencias municipales» (lo cual es otro límite expreso), se deleguen o puedan delegar en las mismas, dejando a salvo, claro, la unidad de gestión del Municipio. En segundo lugar, se prevén los Consejos Sectoriales, como órganos de canalización de la participación de los ciudadanos y de sus asociaciones «en los asuntos municipales», con meras funciones de informe, y cuyo ámbito territorial puede coincidir con el de las Juntas. Finalmente, como ya sabemos, el ROF abre la posibilidad a que el Pleno pueda crear otros órganos desconcentrados distintos a los anteriores.

Además, en este mismo contexto, debemos asimismo mencionar la Carta Europea de Autonomía Local (Estrasburgo, 15 de octubre de 1985, BOE de 24 de febrero de 1989; en España entró en vigor el 1 de marzo de 1989), pues, sobre la base de reconocer el derecho y la capacidad de las Entidades Locales para ordenar y gestionar «una parte importante de los asuntos públicos» bajo su propia responsabilidad y en beneficio de sus habitantes, prevé que las mismas deben poder definir por sí mismas las estructuras administrativas internas con las que pretenden dotarse, «con objeto de adaptarlas a sus necesidades específicas y a fin de permitir una gestión eficaz» (arts. 1, 3-1. ${ }^{\circ}$ y 6-1. ${ }^{\circ}$ ); prescripciones en las que encajan de forma ordinaria los órganos desconcentrados.

Desde el punto de vista general, la LBRL, no obstante la amplitud de sistema organizativo establecido, se vio rápidamente desbordada por las exigencias de una vida local rica y dinámica, derivada de las importantes transformaciones sociales, económicas y culturales que han experimentado los Municipios españoles desde las últimas décadas del siglo XX; principalmente respecto al modelo orgánico-funcional y al rígido uniformismo del régimen de los mismos, sin tener en cuenta su población o complejidad.

13 Quintana LóPEZ, T., «La desconcentración en la organización de los Municipios», trabajo citado, págs. $150-151$ y $155-158$. 
Respecto al primer ámbito, la Ley 11/1999, de 21 de abril (BOE del 22), modificó la LBRL en el contexto del conocido Pacto Local del Estado ${ }^{14}$, para fortalecer las funciones gestoras y ejecutivas de los Alcaldes y Presidentes de las Entidades Locales y, como contrapeso, se mejoró el régimen de las mociones de censura y del control del Pleno, y se introdujo la moción de confianza, entre las cuestiones más destacables. Respecto al segundo aspecto, nada hizo la reforma de 1999, teniendo que esperar hasta la Ley de Modernización de 2003.

En efecto, la Ley 57/2003, de 16 de diciembre, de Medidas para la Modernización del Gobierno Local (BOE del 17) ${ }^{15}$, profundiza más en los aspectos orgánico-funcionales del régimen local y rompe el rígido carácter uniforme de la Administración Municipal al regular el régimen de los Municipios de Gran Población. Las modificaciones más destacables hacen referencia a las funciones del Pleno y del Alcalde o Presidentes de Diputación; denominación de las antiguas Comisiones de Gobierno como Junta de Gobierno Local o Junta de Gobierno; se modifica el régimen de la Mancomunidades Municipales (respecto a sus potestades y para permitir su constitución entre Municipios de diferentes Comunidades Autónomas); mayores competencias para las Provincias; medidas sobre participación ciudadana en el ámbito local; mejoras en la gestión de servicios públicos y respecto a los Consorcios; modificaciones en la Comisión Nacional de Administración Local; creación de órganos de cooperación entre la Administración General de Estado y las Administraciones Autonómicas (destacándose la creación de la Conferencia de Ciudades en el seno de la Conferencia Sectorial de Asuntos Locales), y el régimen de las infracciones y sanciones de las Entidades Locales en diversas materias, acabando así con los problemas del pasado sobre su ejercicio. No obstante, la reforma más destacable de la Ley es

14 Sobre el Pacto Local nacional, vid. Ministerio DE ADMINISTRACIONES PÚBLICAS, «El Pacto Local. Medidas para el desarrollo del Gobierno Local», Ed. INAP-MAP-FEMP, Madrid, 1999; MÁrQUEZ CRUZ, G., «Gobierno Local y Pacto Local (de las Medidas para el desarrollo del Gobierno Local a los Pactos Locales Autonómicos)», Revista Gallega de Administración Pública, n. ${ }^{\circ}$ 25/2000; ORDUÑA REBOLlO, E., «Municipios y Provincias. Historia de la Organización Territorial Española», obra citada, y VARIOS AUTORES, «El desarrollo del Gobierno Local (Una aproximación doctrinal)», Ed. INAP, Madrid, 1999.

15 Respecto a esta importante reforma legislativa, véanse BALLESTEROS FERNÁNDEZ, A. (Coord.), y otros, «Modernización del Gobierno Local», Ed. El Consultor, Madrid, 2004; CARRo FERnÁNDEZ-VALMAYOR, J. L. (Coord.), y otros, «La Modernización del Gobierno Local: Estudios sobre la Ley 57/2003, de 16 de diciembre, de Medidas para la Modernización del Gobierno Local», Ed. Atelier, Barcelona, 2005; GALÁN GALÁN, A., «El régimen especial de los municipios de gran población», Anuario del Gobierno Local 2003, Ed. Fundación Democracia y Gobierno Local, Barcelona, 2004; GuTiÉRREZ ColominA, V., y RUIZ GALDÓN, J. M., «Manual Práctico para la aplicación de la Ley de Medidas para la Modernización del Gobierno Local», Ed. Fundación Asesores Locales, Málaga, 2004; Mozo AMO, J., «La Ley 57/2003, de 16 de diciembre, de Medidas para la Modernización del Gobierno Local, desde la perspectiva de los pequeños Municipios», $R e$ vista de Estudios Locales, n. ${ }^{\circ}$ 73/2004. De forma más general y amplia, véanse, FUERTES LóPEZ, F. J., «Ley Básica del Régimen Local», Ed. COSITAL-Ed. Thomson-Aranzadi, Cizur Menor (Navarra), 2004; REBOLLO PUIG, M., e IZQUIERDO CARRASCO, M., «Comentarios a la Ley reguladora de las Bases del Régimen Local», Ed. Tirant Lo Blanch, Valencia, 2006; MARTí HernándEZ, P., «Problemática del Gobierno de las Grandes Ciudades», El Consultor, n. ${ }^{\circ} 7$ bis/2006, págs. 1476 y ss., y VARIOS AUTORES, «Jornadas sobre la Ley de Medidas para la Modernización del Gobierno Local», Ed. Excmo. Ayuntamiento de Madrid, Madrid, 2004 [http://www.munimadrid.es]. 
EL RÉGIMEN DE LAS COMPETENCIAS Y DE LOS LÍMITES DE LOS DISTRITOS...

la regulación de los Municipios de Gran Población (Título X-LBRL, arts. 121 a 137), al reconocer a estos nuevas formas organizativas y funcionales (nueva composición de la Junta de Gobierno Local, con miembros que no son Concejales; configuración novedosa del Pleno y del Alcalde; introducción de los Distritos, del Consejo Social y de la Comisión de Sugerencias y Reclamaciones; nuevo régimen de la organización interna de los servicios municipales, y creación del Observatorio Urbano, en el Ministerio de Administraciones Públicas).

Naturalmente, además de la normativa básica y general, asimismo debe tenerse en cuenta la legislación autonómica en la materia y las propias normas municipales en la materia (algunas de las cuales se analizarán más adelante).

\section{2) El régimen jurídico vigente ${ }^{16}$}

Aunque quizás un poco tarde, finalmente la Ley de Modernización del Gobierno Local de 2003, al introducir en la LBRL un régimen especial para los Municipios de Gran Población, asume la compleja estructura territorial y poblacional de España (al menos en esta cuestión), permitiendo así que la estructura organizativa de los Municipios sea diversa, y más adecuada, en función de tales circunstancias. Situación, y cambios, que afectan naturalmente a la regulación de los órganos desconcentrados expuesta anteriormente; incidiendo particularmente en la potenciación de los mismos en los Municipios más complejos por razones poblacionales y urbanísticas.

En efecto, de acuerdo con las modificaciones de 2003, la LBRL distingue con claridad (art. 19-3. ${ }^{\circ}$ ) el régimen de organización común (aplicable a la gran mayoría de los Municipios) y el aplicable a los Municipios más grandes, debiendo tenerse en cuenta asimismo los regímenes especiales establecidos para Ma-

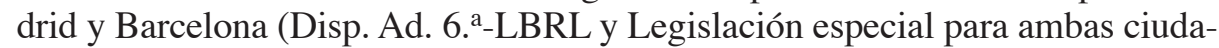
des, que mencionaremos más adelante); diversidad que afecta a la regulación de los órganos desconcentrados, aunque debe resaltarse que el art. 6-LBRL reafirma con carácter general, de acuerdo con el art. 103-CE, la aplicación del principio de desconcentración en las Entidades Locales; teniendo en cuenta, como ya señalamos, asimismo lo dispuesto en la Carta Europea de la Autonomía Local.

En relación con los Municipios a los que se les aplica el régimen organizativo común, y teniendo en cuenta la distinción entre órganos necesarios y complementarios (arts. 19-3. ${ }^{\circ}$ y 20-LBRL), la previsión de crear órganos desconcentrados, como ya sabemos, se vincula a la participación ciudadana (de acuerdo con

16 Galán Galán, A., «Valoración general. La desconcentración territorial en los Municipios: los Distritos», citado; FUERTES LÓPEZ, F. J., «Ley Básica del Régimen Local», citado; REBOLLO PUIG, M., e IZQUIERDO CARRASCO, M., «Comentarios a la Ley reguladora de las Bases del Régimen Local», obra citada, y DoMiNGo Zaballos, M. J. (Coord.), y otros, «Comentarios a la Ley Básica de Régimen Local», citado (los comentarios a los arts. 24 y 128 son de ROMERO HERNÁNDEZ, F.). 
la definición de los Municipios como cauces de participación inmediata en los asuntos públicos que hace su art. 1) y atendiendo a las características del asentamiento de la población en el término municipal, debiendo respetarse la unidad de gobierno y gestión del Municipio, como ya sabemos (art. 24-LBRL). No obstante lo anterior, y de acuerdo con el art. 20-LBRL, las Leyes regionales sobre régimen local pueden establecer una organización complementaria a la establecida y los propios Municipios, en sus Reglamentos Orgánicos, podrán establecer y regular otros órganos complementarios, de conformidad en este caso con la propia Ley de Bases y con las Leyes autonómicas señaladas. Siendo posible, pues, que tales normas municipales (si bien, por su carácter más general, en este trabajo únicamente manejamos las normas básicas y las autonómicas) establezcan órganos desconcentrados para una mejor gestión administrativa; incluso siguiendo la regulación que para los Distritos establece la propia LBRL.

La información y participación ciudadanas se regulan con detalle en los arts. 69 a 72-LBRL, añadiéndose los arts. 70 bis y 70 ter por la Ley de Modernización de 2003 y por la nueva Ley de Suelo de 2007, teniendo el primero una especial incidencia para la desconcentración municipal. De acuerdo con la definición de los Municipios que hace su art. 1, la LBRL prevé que las Corporaciones Locales facilitarán la más amplia información sobre su actividad y la participación de los ciudadanos en la vida local; debiendo las mismas establecer las formas, medios y procedimientos de participación en el ejercicio de su potestad de autoorganización, aunque al realizarlo no podrán en ningún caso menoscabar las facultades de decisión que ostentan los órganos representativos regulados en la Ley, de acuerdo con lo establecido en los arts. 137 y 140-CE, al reafirmar la autonomía local y su carácter democrático (art. 69-LBRL). En este sentido, más destacable es el nuevo art. 70 bis, que obliga a los Ayuntamientos a establecer y regular en normas orgánicas procedimientos y órganos adecuados para la efectiva participación de los vecinos en los asuntos de la vida pública local, «tanto en el ámbito del municipio en su conjunto como en el de los distritos, en el supuesto de que existan en el municipio dichas divisiones territoriales»; enfatizando esta finalidad participativa resaltada en la Ley de Modernización y vinculando su regulación a la complejidad territorial concreta del Municipio, pues la efectiva participación se ha de llevar a cabo en el conjunto del mismo (que es el supuesto ordinario de los Municipios que no han de crear Distritos obligatoriamente) o, si existen, en el ámbito de estos últimos.

Por otra parte, como ya señalamos, y al no haberse modificado después en este punto, el art. 20 del Texto Refundido de Régimen Local prevé la posibilidad, de acuerdo con el Reglamento Orgánico del Municipio, de que los Alcaldes nombren un representante personal en cada uno de los poblados y barriadas separados de casco urbano, y que no constituyan Entidad Local, así como en las ciudades en que el desenvolvimiento de los servicios así lo aconseje.

Además, también sin cambios posteriores, y con el carácter de norma supletoria, el art. $1-4 .^{\circ}$ del ya citado Reglamento de Población y Demarcación Terri- 
EL RÉGIMEN DE LAS COMPETENCIAS Y DE LOS LÍMITES DE LOS DISTRITOS...

torial reafirma la competencia del Ayuntamiento para dividir el término municipal en distritos y en barrios, y establecer variaciones en los mismos.

Más destacable y detallada, tal como señalamos, también sin cambios, y asimismo con naturaleza jurídica supletoria, es la regulación de los órganos desconcentrados en el Reglamento de Organización y Funcionamiento, que, como órganos complementarios de las Entidades Locales territoriales, se prevén en el art. 119 y se regulan en los arts. 122 y 128 a 133, si bien el Pleno puede establecer otros distintos (art. 132); reafirmando el carácter potestativo de los mismos en estos Municipios. En efecto, el art. 122-ROF establece, en primer término, la posibilidad de que en cada uno de los poblados y barriadas separados del casco urbano, y que no constituyan Entidad Local, el Alcalde pueda nombrar un representante personal, que tiene el carácter de autoridad en el cumplimiento de sus funciones, entre los residentes en los mismos, así como en aquellas ciudades en que el desenvolvimiento de los servicios así lo aconseje; representante que ha de estar avecindado en el propio núcleo y cuyo mandato está sujeto al del Alcalde, quien podrá removerlo cuando lo juzgue oportuno. Seguidamente, el art. 128-ROF establece que el Pleno municipal podrá crear Juntas Municipales de Distrito, con el carácter de órganos territoriales de gestión desconcentrada y con la finalidad de mejorar la gestión de los asuntos de competencia municipal y facilitar la participación ciudadana. Para su regulación (composición, organización y ámbito territorial de las mismas) se prevé un Reglamento, que es parte integrante del Reglamento Orgánico municipal, en el que se deben precisar las funciones administrativas que, en relación a las competencias municipales, se deleguen o puedan delegar en las mismas, dejando a salvo, claro, la unidad de gestión del Municipio. Además, se prevén, ya sin carácter territorial, los Consejos Sectoriales, como órganos de canalización de la participación de los ciudadanos y de sus asociaciones «en los asuntos municipales», con meras funciones de informe, si bien su ámbito territorial puede coincidir con el de las Juntas, en cuyo caso su presidencia recaerá en un miembro de la Junta y su actuación estará en relación con el ámbito de la misma (arts. 130 y 131-ROF). El funcionamiento de las Juntas de Distrito se rige por las normas que acuerde el Pleno, rigiendo supletoriamente las aplicables a este, y los Consejos Sectoriales se rigen por los acuerdos plenarios que los establezcan (art. 139-ROF). Finalmente, como ya hemos señalado, el ROF (art. 132) abre la posibilidad a que el Pleno pueda crear otros órganos desconcentrados distintos a los anteriores; dando plena libertad, en el marco jurídico, para adecuar mejor su organización a las peculiaridades del Municipio correspondiente.

En segundo lugar, la Legislación Básica, modificada por la Ley de Modernización de 2003, regula un régimen organizativo especial, y obligatorio, para los llamados Municipios de Gran Población (nuevo Título X, arts. 121 a 138LBRL; disposiciones que gozan de prevalencia frente a las demás normas de igual o inferior rango, ex Disp. Ad.11. a); régimen que con peculiaridades tam- 
bién se aplica a Madrid y Barcelona (Disp. Ad. 6. ${ }^{\text {a }-L B R L ~ y ~ L e g i s l a c i o ́ n ~ e s p e-~}$ cial para ambas ciudades, que se mencionará más adelante).

Este régimen se aplica a los Municipios con población superior a 250.000 habitantes; a los que sea capitales de Provincia con población superior a 175.000 habitantes; a los Municipios que sean capitales de Provincia, capitales autonómicas o sedes de las Instituciones autonómicas y a los Municipios con más de 75.000 habitantes que presenten circunstancias económicas, sociales, históricas o culturales especiales; si bien en los dos últimos casos se exigirá una decisión en tal sentido de la Asamblea Legislativa correspondiente a iniciativa del propio Ayuntamiento (art. 121-LBRL, que precisa además cuestiones más concretas sobre el despliegue de tal sistema).

Sin perjuicio de las demás peculiaridades organizativas de estos Municipios, de acuerdo con lo establecido en el art. 24-2. ${ }^{\circ}$, la LBRL (art. 128) establece, de forma taxativa, que sus Ayuntamientos deberán crear Distritos; prescripción de obligatoriedad que puede ser entendida como un límite a la capacidad de decisión de estos Municipios, precisamente aquellos que por su entidad cuantitativa se presupone que son los mejor preparados para decidir si crean los Distritos o no, en función de su situación concreta; a lo cual puede oponerse la idea de que el Legislador Básico, al obligar a su creación, da por supuesta su necesidad dada precisamente la entidad de estos Municipios de Gran Población.

Así, los Distritos son concebidos en estos Municipios como divisiones territoriales propias, dotadas de órganos de gestión desconcentrada, con la finalidad de impulsar y desarrollar la participación ciudadana en la gestión de los asuntos municipales y su mejora, dejando a salvo la unidad de gobierno y gestión municipal. La decisión de creación de los Distritos corresponde al Pleno municipal, así como la determinación y regulación de sus órganos y sus competencias, sin perjuicio de las atribuciones del Alcalde para fijar la organización y competencia de su administración ejecutiva (ex art. 123-1. ${ }^{\circ}, \mathrm{c}-\mathrm{LBRL}$ ), y determinar en una norma orgánica el porcentaje mínimo de los recursos presupuestarios de la Entidad a gestionarse por los Distritos. Asimismo, se establece que la presidencia del Distrito corresponderá en todo caso a un Concejal.

Por otra parte, debe resaltarse que la desconcentración supone una reordenación normativa (art. 12-2. ${ }^{\circ}$, LRJ-PAC) que no puede revocarse o ser afectada por un mero acto administrativo del órgano que realizó la misma, sino que es necesario dictar otra norma jurídica que proceda a realizar la operación en sentido inverso. Cuestión que supone una garantía para los órganos desconcentrados creados, y para el cumplimiento adecuado de sus finalidades, al darle una cierta tranquilidad.

Además, en este mismo sentido, la creación y regulación de los Distritos ha de hacerse, precisamente, por el Pleno municipal y en una norma de carácter orgánico (arts. 22, 24, 123 y 128-LBRL y art. 129-ROF); previsiones que pue- 
EL RÉGIMEN DE LAS COMPETENCIAS Y DE LOS LÍMITES DE LOS DISTRITOS...

den entenderse como una garantía para los mismos o como un cierto límite, al no tener los Municipios mayor libertad para ello, por no poder desentenderse de tales procedimientos para ponerlos en marcha.

\section{COMPETENCIAS Y LÍMITES DE LOS DISTRITOS}

\section{A) Referencias generales}

De acuerdo con lo señalado anteriormente, la delimitación de las competencias y, en su caso, de los límites de los Distritos y de los órganos desconcentrados es esencial para determinar si los mismos cumplen la finalidad para la que se crean, y, más en general, si cumplen con las finalidades que el principio de desconcentración tiene establecidas en el Ordenamiento Jurídico.

En relación a las competencias de los órganos desconcentrados, como ya hemos señalado, el Ordenamiento general no establece directamente ninguna disposición en la materia (así, es visible en el art. 12-2. ${ }^{\circ}$, LRJ-PAC), siendo posible llevar a cabo estos procesos de forma amplia en relación con las competencias del órgano que desconcentra.

No obstante, al menos, podemos hacer referencia a dos límites de carácter general y previo; aunque la normativa general tampoco los menciona directamente. En primer lugar, es necesario que el proceso de desconcentración cumpla su finalidad esencial, la de acercar la acción administrativa a los ciudadanos, redundando así en una mayor eficacia administrativa y una ejecución más rápida de las decisiones, teniendo en cuenta que los órganos administrativamente de niveles inferiores tienen mayor conocimiento, por estar más cerca de los ciudadanos y de la sociedad, de la realidad en la gestión administrativa concreta, por lo que pueden desplegar una mayor capacidad técnica y profesionalidad para resolver los problemas reales que surjan en la acción administrativa. Además, se descongestionan los niveles superiores de la Administración correspondiente, lo que facilitará asimismo el trabajo administrativo, y se propicia la participación ciudadana en ésa actividad administrativa. Finalidades especialmente importantes en el ámbito de los Municipios más complejos por su población o por su estructura urbanística y territorial. Obviamente, y dada la complejidad de la sociedad actual, no será fácil determinar indubitadamente que esa finalidad que justifica la desconcentración no se produce en algún caso concreto.

En segundo lugar, la desconcentración, desde el ámbito competencial, no puede ser de tal magnitud que desdibuje y haga irreconocible la figura del órgano que realiza la desconcentración, o incluso que materialmente desaparezca (en este sentido, la STS de 12 de mayo de 1990, AR. 6979, y el ATS de 27 de marzo de 1992, AR. 2808, hablan de pérdida de competencias de ése órgano); es decir, es necesario que este último mantenga su sentido previsto en el Orde- 
namiento y el protagonismo en la acción administrativa concreta, ya que de otra forma se estaría produciendo materialmente una supresión y sustitución orgánicas, no previstas jurídicamente, ni se realizaría normativamente de forma adecuada. De no respetarse lo anterior se estaría afectando, sin duda, a la autonomía municipal y a su carácter democrático-representativo, según lo establecido en los arts. 137 y 140-CE y en los arts. 1 y 19-LBRL, que han querido precisamente que los Órganos más importantes y representativos de los Municipios sean de existencia necesaria, los cuales han de mantenerse siempre, sin perjuicio de que se prevean órganos complementarios de los anteriores, como los Distritos y otros órganos desconcentrados (arts. 19 y 20-LBRL).

En este último sentido, puede traerse a colación la doctrina de la STC 32/1981, de 28 de julio, relativa al asunto de las Diputaciones en la Comunidad catalana (aunque debe resaltarse que el supuesto no es técnicamente similar a los procesos de desconcentración), al señalar que «...la autonomía local ha de ser entendida como un derecho de la comunidad local a participar a través de órganos propios en el gobierno y administración de cuantos asuntos le atañen.../...Para el ejercicio de esa participación en el gobierno y administración en cuanto les atañe, los órganos representativos de la comunidad local han de estar dotados de las potestades.../...Ni la gestión desconcentrada puede ser sustitutivo de la descentralización, que implica autonomía, ni podría la lícita transferencia a las comarcas u otras entidades territoriales de competencias hoy atribuidas a las provincias llevarse hasta el extremo de vaciar totalmente a éstas de sus actuales funciones como entes locales, vaciamiento que implica una infracción de los arts. 137, 141 y 142 de la Constitución...»; es decir, no se permite vaciar de competencias a las Provincias, al difuminar las mismas de tal manera que casi supone su desaparición.

\section{B) Competencias y límites de los Distritos en la Legislación Básica $^{17}$}

Debido a la trascendencia que la delimitación de competencias y, en su caso, de límites de los Distritos tiene como órganos desconcentrados, pues a través de ambas se podrá determinar la efectividad concreta de la técnica, y por ello la efectividad de la acción administrativa en relación con los ciudadanos, y la trascendencia organizativa para el propio Municipio, la Legislación Básica establece la necesidad de fijarlas al mencionar la creación de los órganos desconcentrados y, más en concreto, de los Distritos.

\footnotetext{
17 Con carácter general respecto a la técnica de la desconcentración, vid. CORRALES GUILLÉN, J. C., «La desconcentración como principio jurídico y técnica de organización», trabajo citado.

Respecto a los Distritos, en general, véanse GALÁn GALÁN, A., «Valoración general. La desconcentración territorial en los Municipios: los Distritos», citado; Rebollo PUIG, M., e IzQUIERdo CARRASCO, M., «Comentarios a la Ley reguladora de las Bases del Régimen Local», obra citada, y Domingo ZABALLOS, M. J. (Coord.), y otros, «Comentarios a la Ley Básica de Régimen Local», citado (los comentarios a los arts. 24 y 128 son de ROMERO HERNÁNDEZ, F.).
} 
EL RÉGIMEN DE LAS COMPETENCIAS Y DE LOS LÍMITES DE LOS DISTRITOS...

Así, respecto a los Municipios de régimen organizativo común, el art. 24LBRL permite que los mismos puedan establecer órganos de gestión desconcentrada, «con la organización, funciones y competencias que cada Ayuntamiento les confiera», y, respecto a los Municipios de Gran Población, de acuerdo con lo establecido en el art. 24-2. ${ }^{\circ}$, la LBRL, en el art. 128, obliga a la creación de los Distritos «en los términos y con el alcance de lo previsto en el artículo 123», que encomienda al Pleno Municipal la división del mismo en Distritos, «y la determinación y regulación de los órganos de los distritos y de las competencias de sus órganos representativos y participativos»; realizando la precisión funcional directamente a ésos órganos, al no tener los Distritos, obviamente, personalidad jurídica. En el mismo sentido, el art. 129-2. ${ }^{\circ}$, ROF, establece que el Reglamento de las Juntas Municipales de Distrito, que regula, determinará las funciones administrativas que, en relación a las competencias municipales, se deleguen o puedan delegarse.

Teniendo los Distritos la naturaleza de órganos complementarios y siendo posible que tanto las normas autonómicas como las propias municipales establezcan y regulen estos órganos (ex art. 20-LBRL), lo que supone una apreciable diversidad en la materia, es asumible que la Legislación Básica no precise más sobre las funciones de estos órganos desconcentrados, pues precisamente la diversidad y las peculiaridades de los Municipios españoles (y ése precepto de la Ley) impiden que haya un régimen mínimo y homogéneo para todos los Distritos u órganos similares (sin perjuicio de lo que se añadirá más adelante), debiendo tener los mismos las competencias necesarias para cumplir su finalidad, pero asimismo deben adaptarse a la situación concreta y a la complejidad del Municipio que los crea. Precisión que con claridad incluye el art. 24-LBRL para los Municipios de régimen organizativo común, al establecer que la creación de estos órganos desconcentrados ha de atender «a las características del asentamiento de la población en el término municipal», quizás porque este régimen se aplica a la gran mayoría de los Municipios españoles, muy heterogéneos al integrar pequeños, medianos y grandes (ya que los Municipios de Gran Población finalmente serán pocos, y, aunque respecto de éstos el art. 128 no incluye una prescripción parecida, estructurarán sus Distritos de una forma adecuada a sus peculiaridades territoriales y poblacionales, legalmente por derivación del principio de desconcentración aplicable a todos los Municipios según la previsión del art. 6-LBRL). En este sentido pueden entenderse los límites poblacionales que algunas normas autonómicas imponen a los Municipios obligatoriamente para crear Distritos, y que mencionaremos más adelante; si bien con gran diversidad (ya que los límites van desde los 5.000 habitantes, a todas luces insuficientes por sí solos para justificar la creación de Distritos, hasta los 50.000 habitantes).

No obstante esta aparente flexibilidad y amplitud en relación a las competencias de los Distritos, ya señalamos que, como límite, el proceso de desconcentración no puede diluir de tal manera al órgano que realiza la desconcentración, que 
casi se convierta en prescindible y residual. Así en este sentido, obviamente, los Distritos únicamente podrán ejercer las funciones de los Órganos municipales que se desconcentren, en el marco de la regulación de las competencias de éstos establecido, de acuerdo con la Constitución Española, en los arts. 2 y 7, y materialmente en el marco de los arts. 25 a 28-LBRL. Es más, los Órganos municipales (arts. 21 a 23 para los de régimen organizativo común y arts. 122 a 127 para los de gran población) no pueden desconcentrar todas y cada una de las competencias que les han sido concedidas, pues la Ley se las asigna directamente en función de su carácter democrático-representativo (y así algunas de las cuales ni siquiera son delegables en otros Órganos municipales) y porque los Distritos no reflejan, ni necesitan hacerlo, este carácter directamente democrático, pues esta no es su finalidad ni su función general. En este sentido debe interpretarse la referencia del art. 69-2. ${ }^{\circ}$-LBRL a que las formas, medios y procedimientos de participación que las Corporaciones establezcan de acuerdo con su potestad de autoorganización «no podrán en ningún caso menoscabar las facultades de decisión que corresponden a los órganos representativos regulados por la Ley», así como, para los Municipios de Gran Población, la previsión de tener que respetar «las atribuciones del Alcalde para determinar la organización y las competencias de su administración ejecutiva» (art. $\left.123-1 .^{\circ}, \mathrm{c}\right)$; es decir, en última instancia los Distritos no pueden incidir, limitándola, en la función que le corresponde al Alcalde de dirigir la Administración municipal, y ello sin perjuicio de las funciones de la Junta de Gobierno Local (art. 124-4. $\left.{ }^{\circ}, \mathrm{b}-\mathrm{LBRL}\right)^{18}$.

Además, los Distritos se califican como «órganos territoriales de gestión desconcentrada» (art. 24-LBRL y art. 128-ROF) o como «órganos de gestión desconcentrada» (art. 128-LBRL), cuya finalidad está bien precisada en la Legislación Básica: «facilitar la participación ciudadana en la gestión de los asuntos locales y mejorar ésta» (art. 24-LBRL), «la mejor gestión de los asuntos de la competencia municipal y facilitar la participación ciudadana en el respectivo ámbito territorial» (art. 128-ROF) o «impulsar y desarrollar la participación ciudadana en la gestión de los asuntos municipales y su mejora» (art. 128-LBRL), es decir, la gestión administrativa ordinaria, con lo que toda competencia o función de un Órgano municipal que no responda a esta finalidad de gestión administrativa, o de mejorarla, no se integraría en los posibles procesos de desconcentración a los Distritos. En este sentido, parece claro que la naturaleza de los Distritos es la de ser un órgano de gestión, así como sus funciones, y no meramente un órgano consultivo, ya que de no entenderse así no parece que tendría mucho sentido la caracterización que de ellos hace la Legislación Básica y, como veremos, también la legislación autonómica; y para desarrollar esta función de gestión administrativa, o de mejorarla, han de poder utilizar las potestades y dictar los actos administrativos adecuados (que

18 Romero Hernández, F., obra citada, en el comentario al art. 128, pág. 2161, entiende que tal mención supone un defecto sistemático de la redacción del art. 123 y que resulta confuso. 
EL RÉGIMEN DE LAS COMPETENCIAS Y DE LOS LÍMITES DE LOS DISTRITOS...

se imputan directamente a ellos) para cumplir su finalidad última, y no sólo de carácter consultivo ${ }^{19}$.

Naturalmente, el ejercicio de estas funciones de gestión de los Distritos necesita para su efectividad la correspondiente previsión presupuestaria, pues de otra forma la finalidad de los mismos quedaría mermada de forma apreciable. En este sentido debemos entender la previsión directa, para los Municipios de Gran Población, de que el Pleno fije «el porcentaje mínimo de los recursos de la Corporación que deberán gestionarse por los distritos, en su conjunto» (art. 128-2. ${ }^{\circ}$, LBRL), lo cual también puede entenderse como un límite para la actuación de los Distritos (al poderse argumentar que ésa financiación ha de ser siempre la necesaria para el adecuado cumplimiento de sus funciones; si bien, para el resto de los Municipios de régimen común, al procederse a crear los órganos desconcentrados se han de prever los fondos financieros necesarios para que desarrollen sus funciones; aunque en este caso, no hay previsión legal directa sobre este punto).

La determinación de las competencias de los Distritos, y su ejercicio por éstos, tiene un límite último (sin perjuicio de otros establecidos en la Legislación autonómica o en la propia normativa municipal) procedente de su propia naturaleza de órgano desconcentrado, que mantiene la preponderancia de los órganos democrático-representativos de los Municipios y que cierra el sistema, cual es que la creación, articulación y desarrollo de los Distritos y demás órganos desconcentrados ha de dejar a salvo y respetar «la unidad de gobierno y gestión del Municipio» (arts. 24 y 128-LBRL; y en parecido sentido también art. 129-ROF). Límite general y amplio, establecido por la Legislación Básica, que conecta con lo dicho anteriormente respecto a la finalidad de la desconcentración y a la necesaria preponderancia de los Órganos municipales que ostentan la representatividad democrática en los Ayuntamientos correspondientes

19 Vid. CoRRALEs GuilLéN, J. C., «La desconcentración como principio jurídico y técnica de organización», citado, págs. 186-187, señala que las competencias desconcentradas se refieren a las de «carácter horizontal (personal, contratos, patrimonio, gestión económica y presupuestaria y subvenciones, entre otras), sin extenderse a aquellas que se corresponden con las funciones de dirección política, las propias de las relaciones institucionales o al ejercicio de la potestad reglamentaria», y MESEGUER YEBRA, J., «La competencia administrativa y sus modulaciones...», obra citada, págs. 35-53, y «La desconcentración como técnica de modulación competencial interorgánica...», citado, 139-140.

Concretamente, respecto a los Distritos, véanse GALÁN GALÁN, A., «Valoración general. La desconcentración territorial en los Municipios: los Distritos», citado, págs. 135-142, que plantea con claridad el debate en la cuestión; Rebollo Puig, M., e IZquierdo CARRASCO, M., «Comentarios a la Ley reguladora de las Bases del Régimen Local», obra citada; Domingo ZABALlos, M. J. (Coord.), y otros, «Comentarios a la Ley Básica de Régimen Local», citado (teniendo en cuenta que ROMERO HERNÁNDEZ, F., en el comentario al art. 24, pág. 399, se inclina por calificarlos como órganos no resolutivos), y MORELL OCAÑA, L., «Madrid. Comentarios al articulado de la Ley de Régimen Especial y de Capitalidad», Ed. Thomson-Civitas, Cizur Menor (Navarra), 2007, págs. 396-397, que distingue, adecuadamente, al analizar las competencias de los Distritos, las funciones de colaboración a la formación de la política municipal (mediante la formulación de propuestas e informes), competencias de dirección y gestión (en particular en materias de equipamientos colectivos y servicios públicos), competencias para otorgar licencias y autorizaciones (al ser ellas las que permiten entablar una relación directa con los administrados), e igualmente la contratación de obras y servicios, dentro de determinada cuantía, y finalmente todo cuanto tenga que ver con la participación ciudadana y la promoción de ayudas asociativas. 
(así, art. 69-2. ${ }^{\circ}$ LBRL), ya que la creación de los Distritos y su despliegue no se hace para incidir negativamente en la unidad de la acción de gobierno y gestión municipales. Principio que, por su carácter básico, ha de ser desarrollado y precisado por la Legislación autonómica y por las propias normas municipales, previendo y modulando los distintos instrumentos y mecanismos para garantizar este principio de unidad en el gobierno y en la gestión municipal.

No obstante, la propia Legislación Básica incluye algunos límites que se justifican precisamente en la necesidad de mantener la unidad del gobierno y la gestión municipales. Así, podemos mencionar la imposibilidad legal de que las formas, medios y procedimientos de participación que puedan establecer las Corporaciones puedan menoscabar las facultades de decisión de los órganos representativos correspondientes (art. 69-2. ${ }^{\circ}$, LBRL), la previsión de que la creación de los órganos desconcentrados corresponde siempre al Pleno municipal (arts. 22-2. ${ }^{\circ}, \mathrm{b}$, para los Municipios de régimen común, y art. 123-1. ${ }^{\circ}$, c, para los de gran población), la previsión de que la presidencia del Distrito corresponderá en todo caso a un Concejal (art. 128-3. ${ }^{\circ}$, LBRL) y el instrumento de mayor importancia para mantener tal unidad de gobierno y gestión municipales, cual es el de prever la posibilidad de recurrir las decisiones de los órganos de los Distritos ante los órganos superiores del Ayuntamiento ${ }^{20}$.

\section{C) Competencias y límites de los Distritos en la Legislación autonómica}

La Legislación autonómica, de acuerdo con el art. 20-LBRL, puede establecer una organización municipal complementaria a la prevista como obligatoria en el mismo precepto; Legislación, por tanto, que hemos de tener en cuenta para precisar las competencias y límites de los Distritos en la actualidad, en el marco de lo establecido en la Legislación Básica.

\section{1) Comunidad Autónoma de Andalucía 21}

El nuevo Estatuto de Autonomía, aprobado por Ley Orgánica 2/2007, de 19 de marzo (BOE del 20), que ha sido recurrido ante el Tribunal Constitucional,

\footnotetext{
20 Por todos, QuintAnA LÓPEZ, T., «La desconcentración en la organización de los Municipios», obra citada, págs. 151-155; CoRRAles GuILlÉN, J. C., «La desconcentración como principio jurídico y técnica de organización», trabajo citado, y GALÁN GALÁN, A., «Valoración general. La desconcentración territorial en los Municipios: los Distritos», trabajo citado, págs. 142-147.

21 Sobre el Estatuto de Autonomía anterior, en que se basa la Ley que se cita, vid. PÉrEZ MORENO, A., y otros, «Comentarios al Estatuto de Autonomía», Ed. Instituto García Oviedo, Sevilla, 1981, y MuÑOZ MACHADO, S. (Dir.), y otros, «Comentarios al Estatuto de Autonomía de la Comunidad Autónoma de Andalucía», Ed. IEAS, Madrid, 1987. En relación a la Administración Local, en esta misma etapa, ver TERRÓN MONTERO, J., «La articulación territorial de la Comunidad Autónoma de Andalucía», en PORRAS-NADALES, A., y RUIZ-RICO, J.J., «El Estatuto de Andalucía. Estudio sistemático», Ed. Ariel, Barcelona, 1990, y «La Administración Local en la Comunidad Autónoma de Andalucía», en CÁmara Villar, G., SÁnchez LóPez, J., y TERrón MonTERO, J., «El Estatuto de Autonomía», Tomo III, «El Gobierno y la Administración», Ed. Ariel, Barcelona, 1990.
} 
EL RÉGIMEN DE LAS COMPETENCIAS Y DE LOS LÍMITES DE LOS DISTRITOS...

menciona el principio de desconcentración (art. 90) entre los principios de organización territorial de la Comunidad. Además, el art. 91 reconoce a los $\mathrm{Mu}$ nicipios plena capacidad de autoorganización dentro del marco de las disposiciones generales establecidas por Ley en materia de organización y funcionamiento municipal; previéndose la elaboración de una Ley de régimen local, la cual ha de tener en cuenta las diferentes características demográficas, geográficas, funcionales, organizativas, de dimensión y capacidad de gestión de los distintos Entes Locales.

En el ámbito de la legislación ordinaria, la Ley 3/1983, de 1 de junio, de Organización Territorial (BOJA del 3), menciona el principio de desconcentración al regular la articulación de competencias entre los distintos Entes territoriales de la Comunidad. No existiendo ninguna norma que regule los Distritos en la Comunidad; estándose pues a la propia normativa municipal ${ }^{22}$.

\section{2) Comunidad Autónoma de Aragón ${ }^{23}$}

El Estatuto de Autonomía, aprobado mediante Ley Orgánica 5/2007, de 20 de abril (BOE del 23), recurrido también ante el Tribunal Constitucional, reconoce al Municipio como entidad territorial básica de la Comunidad, y reafirma su consideración como medio esencial de participación de la comunidad vecinal en los asuntos públicos.

La Ley 7/1999, de 9 de abril, de Administración Local (BOA del 17), modificada en 1999, 2001 y 2002, prevé, en su art. 28, la posibilidad de existencia de los órganos complementarios que determine el Ayuntamiento en su Reglamento Orgánico; que, en ejercicio de la potestad de autoorganización, regulará su constitución y funcionamiento, adaptándola a las peculiaridades y necesidades del respectivo Ayuntamiento, respetando la Legislación Básica y los principios que, con el carácter de mínimos, establece la propia Ley.

\footnotetext{
22 En relación a los Distritos en la actualidad, y con expresa referencia tanto a las normas municipales concretas como a las competencias de los mismos, respecto a las ciudades concretas, véanse los trabajos de SAlas CuQuerella, B., «Evolución de los Distritos en Sevilla: una apuesta de profundización en la democracia directa a través de los presupuestos participativos», Ruíz-GALDÓN, J. M., y GUTIÉRREZ COLOMINA, V., «Los Distritos en Málaga», y BAENA GonZÁLEZ, A., «La división territorial en la ciudad de Córdoba», en C. Prieto Romero y A. Galán Galán (Dir.), y otros, «Los Distritos: Gobierno de Proximidad», obra citada, págs. 335-376, 409-442 y págs. 467-488, respectivamente.
}

23 Sobre el Estatuto anterior, en que se basa la Ley señalada, vid. FANLO LORAS, A., «La Administración Local», en EMBID IRUjo, A. (Dir.), y otros, «Derecho Público Aragonés. Estudios sobre el Derecho de la Comunidad Autónoma de Aragón», Ed. Justicia de Aragón e Ibercaja, Zaragoza, 1990. En relación con los aspectos locales en ésa época, ver SALANOVA AlCALDE, R., «La Administración Local en Aragón», Revista aragonesa de Administración Pública, n. ${ }^{\circ}$ 1/1992.

En relación con los Distritos en la actualidad, de forma general y con especial atención a la ciudad de ZaragOza, vid. LASIERRA ESTEBAN, J. M., «Participación ciudadana y desconcentración administrativa territorial en Zaragoza», en C. Prieto Romero y A. Galán Galán (Dir.), y otros, «Los Distritos: Gobierno de Proximidad», obra citada, págs. 377-408. 
Esta Ley prevé varios órganos municipales complementarios, que plasman el principio de desconcentración. En primer lugar la Ley prevé, en su art. 37, la figura de los Alcaldes de Barrio, como representante personal del Alcalde en cada uno de los Barrios separados del casco urbano que no estén constituidos en Entidad Local Menor; su nombramiento ha de recaer en una persona que resida en el Barrio referido (cuestión que, aunque comprensible, puede entenderse como un límite); su duración del cargo está sujeta a la del mandato del Alcalde que lo nombró, quien también podrá removerlo cuando lo juzgue oportuno, y tienen el carácter de Autoridad en el cumplimiento de sus cometidos. No obstante, el régimen anterior es de aplicación supletoria respecto a lo dispuesto en el Reglamento Orgánico u otro Reglamento municipal.

En segundo lugar, el artículo 38 prevé las Juntas de Distrito o de Barrio, a crear potestativamente por el Pleno en Municipios que cuenten con más de 5.000 habitantes (previsión poblacional que parece limitar poco la aplicación de la técnica de desconcentración, y que plantea la duda sobre la justificación de su aplicación a estos Municipios no excesivamente complejos, al menos desde este punto de vista; además, sobre los más de 700 Municipios, con tal población únicamente hay 20), como órganos territoriales de gestión desconcentrada con la finalidad de facilitar la participación ciudadana en la gestión municipal, en los términos previstos en su Reglamento Orgánico o de Participación. Respecto a su composición y organización, y en ausencia de regulación específica, dichas Juntas se integrarán por Concejales y por representantes de las Asociaciones de Vecinos, siendo los Concejales designados por el Alcalde a propuesta de los grupos políticos, y los representantes de las Asociaciones vecinales serán designados por el Alcalde a propuesta de las mismas, y de acuerdo con su efectiva implantación; Juntas que las presidirá el Concejal en quien el Alcalde delegue o el Alcalde de Barrio. Como en el supuesto anterior, este régimen será de aplicación supletoria respecto a lo dispuesto en el Reglamento Orgánico u otro Reglamento municipal.

A continuación, el artículo 39 regula los Consejos sectoriales, a crear potestativamente por el Pleno como órganos colegiados de participación sectorial en relación con los ámbitos de actuación pública municipal, con la finalidad de facilitar y fomentar la participación de las asociaciones y colectivos interesados.

Respecto a las competencias de los anteriores, el artículo 40 establece que les corresponderá, en relación con el territorio o sector de la acción pública correspondiente, formular propuestas y emitir informes, a iniciativa propia o del Ayuntamiento, sobre los diversos aspectos de las competencias municipales y el funcionamiento de sus servicios y organismos. Remitiendo al Reglamento Orgánico o al de Participación Ciudadana la posibilidad también de encomendar a dichos órganos facultades de gestión (quizás en función de la situación concreta del Municipio, aunque nada se dice). 
Por otra parte, y de acuerdo con la finalidad de no propiciar el aumento del número de Municipios, expresada en la propia Exposición de Motivos, párrafo $4 .^{\circ}$, y plasmada en el art. 10-4. (al prever que, en supuestos de núcleos de población de cierta importancia o de sus actividades, sin reunir las condiciones para crear un nuevo Municipio, sea oportuno reconocerles cierta autonomía y pueda instarse la creación de un órgano desconcentrado, o de una Entidad Local Menor, según las circunstancias concretas), la misma Ley de Administración Local, en su artículo 41, regula el régimen de organización de los núcleos separados de la capitalidad; permitiendo que puedan constituirse en ellos Juntas de Vecinos, como órganos territoriales de participación, siendo su constitución obligatoria cuando lo solicite la mayoría de los vecinos interesados. Cuando el núcleo de población tenga menos de cien habitantes, la Junta de Vecinos estará integrada por la totalidad de los electores, presidiéndola el Concejal que a tal efecto designe el Alcalde; en el supuesto de que el núcleo de población tenga cien o más habitantes, la Junta de Vecinos se formará por representación de acuerdo con los criterios establecidos para las Entidades Locales Menores, presidiéndola el Concejal que designe el Alcalde. En ambos casos, su funcionamiento se ajustará a lo previsto en el Reglamento Orgánico municipal y, en su defecto, en las normas supletorias que apruebe la Diputación General de Aragón. En cuanto a las competencias, la Junta de Vecinos podrá ejercer funciones de consulta, propuesta e informe en relación con todas las actuaciones municipales que afecten específicamente al núcleo de población, y de gestión y administración en relación con los equipamientos públicos locales y la organización de actividades festivas, culturales y sociales; debiendo asignar el Ayuntamiento a la Junta los recursos económicos adecuados para el ejercicio de las funciones encomendadas (de forma adecuada, sin fijar cantidad o porcentaje alguno, haciendo depender la cantidad de las funciones previstas). En todo caso, los acuerdos y resoluciones adoptados por la Junta de Vecinos y su Presidente serán susceptibles de impugnación mediante recurso ordinario ante el Alcalde (reafirmando la unidad de gobierno y gestión municipal).

Por su parte, el Reglamento de Territorio y Población de las Entidades Locales, aprobado por Decreto 346/2002, de 19 de noviembre (BOA del 25), regula la situación de los Municipios con núcleos de población diferenciados (arts. 65 y 66), para cuyo reconocimiento se valorará especialmente que varios de esos núcleos superen los doscientos cincuenta habitantes y el esfuerzo económico adicional que suponga la prestación de los servicios obligatorios para el Ayuntamiento. El Municipio interesado en el mismo podrá solicitarlo, acompañado de una memoria justificativa de los núcleos de población y de sus características, debiendo ser acordado por el Pleno municipal. Asimismo, se propondrán los compromisos que el Municipio esté dispuesto a asumir en relación con la creación de Órganos de gestión desconcentrada y con la programación prioritaria de inversiones en dichos núcleos. Igualmente el procedimiento de reconocimiento podrá iniciarse de oficio mediante por la Comunidad Autónoma, previa audiencia a los Ayuntamientos interesados. El expediente se someterá a 
información pública por el plazo de un mes y se dará audiencia al Municipio interesado. La declaración de municipio con elevado número de núcleos de población a los efectos del reconocimiento y aplicación de este régimen especial se efectuará por Decreto del Gobierno de Aragón. Este reconocimiento llevará consigo la especificación de los compromisos que asuma el Ayuntamiento y de los beneficios que pueda obtener como consecuencia del mismo. Su determinación deberá incluirse en el Decreto que reconozca ese régimen especial. En todo caso, entre los compromisos del Municipio deberán especificarse las medidas de participación y desconcentración que vayan a adoptarse, en aplicación de la Ley de Administración Local de Aragón, así como una programación de inversiones de obras y servicios en los núcleos de población.

\section{3) Comunidad Autónoma de Asturias ${ }^{24}$}

El Estatuto de Autonomía, aprobado por Ley Orgánica 7/1981, de 30 de diciembre (BOE de 11 de enero de 1982), y modificado en 1991, 1994 y 1999, establece que la Comunidad se organiza territorialmente en Municipios y que podrán crearse Áreas Metropolitanas (art. 6). En relación a los Distritos, no hay disposiciones autonómicas específicas, siendo de aplicación la Legislación Básica y la normativa local propia (como se refleja en el Reglamento Orgánico de Organización y Funcionamiento de los Distritos de Gijón, de 20 de junio de 2005, BOPA del 9 de julio).

\section{4) Comunidad Autónoma de las Islas Baleares}

El Estatuto de Autonomía, aprobado mediante Ley Orgánica 2/1983, de 25 de febrero (BOE de 1 de marzo), modificada de forma completa por Ley Orgánica 1/2007, de 28 de febrero (BOE del 1 de marzo), prevé que su organización territorial se articula en Islas y Municipios, a regular por la Legislación Básica y por Ley autonómica, y de acuerdo con el principio de desconcentración, entre otros (art. 8). Además, el art. 75 se refiere a los Municipios y a otras Entidades Locales, reafirmando el carácter del Municipio como instrumento fundamental para la participación de la comunidad local en los asuntos públicos, y sin incluir referencias directas a los Distritos, si bien se prevé la elaboración de una Ley de régimen local, en el marco de la Legislación Básica, que deberá tener en cuenta necesariamente las diferentes características demográficas, geográficas, organizativas, de dimensión y capacidad de gestión que tengan los Municipios; debiendo disponer éstos, además, de recursos financieros suficientes. Finalmente, se prevé la elaboración de la Ley especial de capitalidad para el Municipio de Palma.

24 Arce JanÁriz, A. (Coord.), y otros, «El Estatuto de Autonomía del Principado de Asturias. Estudio Sistemático», Ed. Junta General del Principado de Asturias, Llanera (Asturias), 2003 http://paradadel2.googlepages.com/estatuto.pdf 
EL RÉGIMEN DE LAS COMPETENCIAS Y DE LOS LÍMITES DE LOS DISTRITOS...

De acuerdo con tales prescripciones se aprueba la Ley 20/2006, de 15 de diciembre, Municipal y de Régimen Local (BOIB del 27), que reitera que la estructura territorial de la Comunidad se basa en las Islas y en los Municipios, y reafirma el principio de desconcentración entre los principios de organización territorial (arts. 1 y 3 ).

El art. 57 permite que los Ayuntamientos, puedan crear Entes Autónomos Locales, Distritos y Delegaciones Territoriales que, sin tener la condición de Entidades Locales, son formas de organización descentralizada o desconcentrada del Municipio.

Así, se prevé que, cuando lo soliciten la mayoría de los vecinos con derecho a voto en las elecciones municipales, los Ayuntamientos pueden crear, en los núcleos de población separados de la capital del Municipio y de acuerdo con el procedimiento establecido, Entes Autónomos Locales denominados Juntas Vecinales, como órganos territoriales de participación; y que tienen personalidad jurídica (cuestión que permite dudar de que estemos ante un órgano desconcentrado, sino ante un verdadero Ente Público; aunque el primer párrafo del precepto es confuso, pues niega su carácter de Entidad Local) con competencia limitada a las funciones asignadas por el Pleno, que pueden ser modificadas mediante el procedimiento establecido en el acuerdo de creación. Estas Juntas Vecinales se rigen según lo dispuesto por el Pleno. El procedimiento para su creación es el siguiente: elaboración del proyecto, aprobación inicial, información pública por el plazo de treinta días y aprobación definitiva. El proyecto comprenderá la delimitación territorial; el número de miembros de la junta vecinal, sean o no concejales o concejalas, que serán designados por el pleno del ayuntamiento a propuesta de los grupos políticos municipales y en proporción al número de miembros de cada uno de éstos; la forma de designación del presidente o de la presidenta, y las funciones que se encomiendan al ente autónomo local.

Por otra parte, los Distritos son órganos territoriales desconcentrados del Municipio para gestionar de manera más eficaz los asuntos de competencia municipal y para facilitar la participación ciudadana en el respectivo ámbito territorial. Tienen la organización, las funciones y las competencias que cada Ayuntamiento les confiera, atendiendo a las características singulares de las diferentes porciones del término municipal; con lo que la libertad de organización municipal se enmarca en la necesidad de atender a tales características.

Finalmente, los Alcaldes pueden establecer Delegaciones Territoriales en los núcleos de población separados o en los barrios con las funciones que, en cada caso, se les encomienden. Los Delegados pueden ser o no Concejales. En cualquier caso, los Alcaldes deben establecer en dichos núcleos la organización adecuada para la prestación de los servicios mínimos que se determinen reglamentariamente. 
mayor trascendencia tiene la Ley 23/2006, de 20 de diciembre, de Capitalidad de Palma de Mallorca (BOIB del 27), ya que señala con claridad, en su art. 9, que el Gobierno municipal actúa según los principios de eficacia, eficiencia, jerarquía, descentralización, desconcentración y coordinación como criterios esenciales de su organización, prestando especial atención a la participación ciudadana, entre otras cuestiones. Siguiendo el modelo básico y el propio de la Comunidad, en la organización municipal se distinguen órganos necesarios y, en el marco de autoorganización, se prevé que el Ayuntamiento de Palma de Mallorca pueda constituir los órganos complementarios de información, consulta o asesoramiento que considere necesarios para el buen gobierno del $\mathrm{Mu}-$ nicipio (art. 10).

De acuerdo con lo anterior, los arts. 27 a 31 de la Ley regulan la «desconcentración y descentralización de los servicios municipales». En primer término, la Ley establece el régimen de la desconcentración territorial con la finalidad de obtener más eficacia en la prestación de los servicios públicos, para lo que el Pleno, por mayoría absoluta, podrá acordar la desconcentración de las competencias municipales en estructuras territoriales que podrán denominarse Distritos, de manera que se mejore la participación ciudadana y se acerquen las políticas municipales a corregir los desequilibrios y la representación de los intereses de las diversas zonas, barriadas o pueblos de Palma, y cuya actuación se ajustará a los principios de unidad de gobierno, eficacia, coordinación y solidaridad (que suponen, sin duda, límites a los mismos). Con buen criterio (para atender concretamente a la situación del asentamiento real de la población en el mismo), se prevé que la creación de los Distritos pueda afectar a todo el Municipio o a una o diversas zonas del término municipal. Además, la creación de Áreas territoriales puede afectar a todo el Municipio, o a una o a diversas zonas del término municipal. Con la misma mayoría, el Pleno puede modificar o suprimir las mencionadas Áreas y los Órganos territoriales señalados. Por su parte, el Alcalde también puede nombrar y separar Delegados de áreas del Municipio, sin necesidad de crear un órgano territorial.

Los acuerdos anteriores, se establece, contendrán como mínimo la denominación concreta del área, con términos como Distrito, Zona, Barrio, Pueblo u otros similares (debiéndose respetar, si es el caso, las denominaciones tradicionales); los límites referidos a vías de dominio público o al fin del término municipal (aunque, de no ser posibles los límites mencionados, se indicarán en el Área con toda claridad); la denominación del Órgano que se crea y su composición, que será proporcionalmente igual a la composición del Pleno municipal, con la especificación del número de miembros, su presidencia, que necesariamente recaerá en el Alcalde o en un Concejal; sus funciones, y las propias del Presidente.

Las funciones del Presidente del Órgano desconcentrado pueden ser, entre otras, representar al Ayuntamiento en la demarcación territorial, sin perjuicio de la función representativa del Alcalde; convocar las sesiones de ese Órgano, es- 
EL RÉGIMEN DE LAS COMPETENCIAS Y DE LOS LÍMITES DE LOS DISTRITOS...

tablecer su orden del día y presidir sus sesiones; someter al mismo el proyecto de Reglamento de funcionamiento; someter al mismo la propuesta del plan y del programa de actuación para su aprobación; elevar a los Órganos municipales decisorios las propuestas aprobadas por el Órgano desconcentrado; fomentar las relaciones del Ayuntamiento con las entidades cívicas y culturales del área e informar a «las personas administradas» [sic] de la actividad municipal mediante sus órganos de participación; impulsar los servicios y las obras que se realizan en el ámbito territorial del área, y otras que le atribuyan o deleguen los Órganos municipales decisorios.

Por otra parte, se prevé que las funciones del Órgano desconcentrado puedan ser, entre otras, aprobar, a propuesta de su Presidente, el Reglamento interno de organización y funcionamiento; aprobar el programa de actuación del área, y someterlo al Pleno municipal; proponer a los Órganos de Gobierno municipal la inclusión de asuntos en el orden del día, enviándoles propuestas de acuerdos; elaborar estudios sobre las necesidades del área; proponer a los Órganos municipales competentes la aprobación de instrumentos de ordenación urbanística que afecten al ámbito territorial del área; informar, con carácter preceptivo o potestativo, según establezca el Pleno, sobre algunos expedientes (los relativos al programa de actuación municipal, a los instrumentos de ordenación urbanística que afectan al ámbito territorial del área; a los proyectos de equipamiento del área; concesión de viviendas en el ámbito geográfico del área; desarrollo del proceso de descentralización y participación; estudio de las peticiones e iniciativas individuales y colectivas del vecindario para su traslado, con su informe, a los órganos municipales competentes y los presupuestos municipales); controlar y fiscalizar los órganos municipales cuando el ámbito territorial de actuación sea el área referida, y otras que puedan atribuirle o delegar los Órganos municipales decisorios. Además, el art. 32 reconoce la iniciativa y propuesta de aprobación de normas municipales de estos Órganos desconcentrados. Por tanto, como es bien visible, se reconocen escasas funciones de gestión y administración municipales, aunque la frase final del art. 30 podría interpretarse en tal sentido, al tener una redacción muy general y amplia; si bien parece que si se le querían encomendar estas funciones de gestión lo más adecuado hubiera sido hacerlo en el texto de la Ley directamente.

Además, la Ley prevé procesos de «desconcentración y descentralización funcionales», al establecer que el Pleno municipal, el Alcalde y la Junta de Gobierno Local pueden desconcentrar y descentralizar sus competencias en los Concejales, en otros Órganos municipales o en otros Entes locales, respectivamente.

\section{5) Comunidad Autónoma de Canarias}

El Estatuto de Autonomía, aprobado por Ley Orgánica 10/1982, de 10 de agosto (BOE del 16), y modificado en 1996, estructura la organización territorial de la Comunidad sobre las Islas (art. 8), y establece que a los «Ayuntamien- 
tos» [sic], además de sus competencias propias, les corresponderá las que le delegue la Comunidad Autónoma (art. 23).

De acuerdo con la redacción original del Estatuto se aprobó la Ley 14/1990, de 26 de julio, de Régimen Jurídico de las Administraciones Públicas de la Comunidad (BOCAN del 1 de agosto), modificada después, entre otras cuestiones, para adaptarla al Estatuto, que regula de forma integrada todas las Administraciones Públicas canarias, si bien a nivel territorial destacan obviamente las Islas y los Municipios (arts. 1 a 7); regulándose estos últimos en el Título V de la Ley (arts. 56 y ss.). Siguiendo lo establecido en la Legislación Básica, se prevén, en el sistema de organización municipal, órganos necesarios (denominados básicos en el texto) y otros de carácter complementario, entre los que se incluyen órganos de gestión desconcentrada y de participación vecinal (las Juntas Municipales de Distrito) y órganos de participación vecinal (los Consejos de Distrito o Barrio y los Consejos Sectoriales) (art. 62).

Las Juntas Municipales de Distrito o de Barrio (arts. 96 a 106) son órganos territoriales de gestión colegiada y desconcentrada en que se posibilitará la más amplia y efectiva participación ciudadana, a crear en los Municipios que superen 50.000 habitantes (límite poblacional que parece más adecuado que otros señalados para justificar la creación de Órganos desconcentrados); regulándose con detalle su composición, en función de los habitantes. Estas Juntas ostentan competencias «delegadas» de la Alcaldía y de la Junta de Gobierno Local, «tendiendo de esta forma a mejorar la gestión y a facilitar la participación ciudadana en la misma»; debiendo actuarse en el momento de la delegación de acuerdo con los principios de eficacia, descentralización, desconcentración y coordinación, en el marco de la Legislación Básica. Las Juntas Municipales están presididas por un Concejal designado por el Alcalde, dando cuenta al Pleno, que representa al Alcalde en el Distrito; Concejal que preside todos los órganos de las Juntas, que son el Pleno de la misma, el equipo de gobierno y los Consejos Sectoriales, siendo únicamente delegable la presidencia de los últimos. El Pleno de la Junta, compuesto por el Presidente y los vocales, y actuando como secretario el jefe de la Oficina Municipal del Distrito, tiene funciones de control y fiscalización del Presidente y del equipo de gobierno. Por su parte, el equipo de gobierno, presidido por el Concejal referido y compuesto por vocales de la mayoría municipal, siempre contando con los Presidentes de los Consejos de Participación, es el órgano de asistencia al Presidente y de gestión y gobierno colectivo de la Junta. Los Consejos de Participación son órganos de estudio, asesoramiento, propuesta y seguimiento de la gestión, que incluyen en su composición a miembros de las entidades ciudadanas y de los vecinos, y que tienen por funciones el estudio de los problemas de los Distritos en los ámbitos de la competencia específica, conocer e informar los asuntos a tratar en el Pleno de la Junta, elevación de propuestas a la Junta Municipal sobre los problemas reseñados, realizar el seguimiento de los acuerdos de la Junta y participar en las actividades realizadas en el Distrito. 
Seguidamente, la Ley regula los Consejos de Barrio y los Consejos Locales de Sector, como órganos de participación ciudadana, si las características del Municipio y de su población no aconsejasen la implantación de entes de gestión desconcentrada. Los Consejos de Barrio son órganos territoriales para facilitar la participación ciudadana en el Gobierno municipal, presididos por «un representante de la Corporación que será su Presidente», y compuestos por representantes de Asociaciones de Distrito y vecinos. Sus funciones son de carácter informativo y de proposición de soluciones a los problemas específicos del Barrio para su conocimiento y eventual discusión por la Corporación Municipal; debiendo por ello los Ayuntamientos recabar informe en los asuntos que afecten a los Barrios. Por su parte, los Consejos Municipales de Sector [sic] son órganos sectoriales para facilitar la participación ciudadana en el Gobierno municipal, compuestos por el Concejal Delegado del Servicio, que es su Presidente, y por representantes de las entidades con interés e incidencia en el sector de que se trate, y con funciones de informe al Ayuntamiento de los temas específicos y proponer alternativas concretas, de consulta por el Delegado del Sector en asuntos de trascendencia y participar en el seguimiento de la gestión municipal en los asuntos probados.

\section{6) Comunidad Autónoma de Cantabria}

El Estatuto de Autonomía, aprobado mediante Ley Orgánica 8/1981, de 30 de diciembre (BOE del 11 de enero de 1982), y modificado en 1998 y 2002, apenas contiene disposiciones sobre la Administración Local, pues únicamente prevé que Cantabria estructura su organización territorial en Municipios y que una Ley podrá reconocer la Comarca como entidad local con personalidad jurídica y demarcación propia; no suponiendo, necesariamente, la supresión de los Municipios que la integran (art. 2). En base al mismo, se han elaborado exclusivamente Leyes sobre Entidades Locales Menores en 1994 y sobre Comarcas en 1999.

\section{7) Comunidad Autónoma de Castilla-La Mancha}

Su Estatuto de Autonomía, aprobado por Ley Orgánica 9/1982, de 10 de agosto (BOE del 16), y modificado en 1994, 1997 y 2002, prevé que una Ley regulará la organización territorial propia de la región (art. 2); estableciendo que la misma se basará en Municipios y Provincias, aunque se permiten otros Entes Locales (art. 29). De acuerdo con lo anterior, se aprobó la Ley 3/1991, de 14 de marzo, de Entidades Locales (DOC-LM del 27), y modificada en 1995, 1998, 1999 y 2000, que no incluye referencia alguna a órganos desconcentrados. 


\section{8) Comunidad Autónoma de Castilla y León ${ }^{25}$}

El anterior, y derogado, Estatuto de Autonomía de la Comunidad, aprobado mediante Ley Orgánica 4/1983, de 25 de febrero (BOE de 2 de marzo), y modificado en 1994 y 1999, en los arts. 25 y 26, regulaba la organización territorial de la Comunidad. El art. 25 reconocía, en primer lugar, la autonomía y la personalidad jurídica de los Municipios (concebidos como la entidad territorial básica de la Comunidad; gozando de personalidad jurídica propia y de plena autonomía para la gestión de sus intereses; correspondiendo su representación, gobierno y administración a sus respectivos Ayuntamientos) y de las Provincias (considerándolas el ámbito territorial para el desarrollo y gestión de las competencias y funciones de la Comunidad). A continuación, se preveía la regulación, por Ley, con carácter general, de la organización y funcionamiento de las Comarcas, y su propia creación. Finalmente, también, se establecía la regulación, por Ley y en el marco de la Legislación Básica, de las Entidades Locales Menores y otras formas tradicionales de organización municipal, así como que se regularía la creación y reconocimiento de las Mancomunidades y otras agrupaciones de Municipios. Por su parte, el art. 26-EACYL regulaba las relaciones entre la Comunidad y las Entidades Locales, partiendo de señalar los principios básicos y en el marco de la Legislación estatal y del propio Estatuto; en base a lo cual, se remitía a una Ley la regulación de la coordinación de las funciones de las Diputaciones Provinciales y otras Entidades, y la transferencia o delegación de facultades correspondientes a materias de competencia de la Comunidad en las Diputaciones y demás Entidades Locales. Además, y conviene destacarlo, la Comunidad asumía como obligación especial el apoyo financiero a las Entidades Locales, a cuyo fin debía dotar un fondo de cooperación local adecuado, sin perjuicio de otros instrumentos de cooperación.

Actualmente, se ha tramitando y aprobado por las Cortes Generales un nuevo Estatuto de la Comunidad. En efecto, después de las negociaciones entre los Par-

25 En general sobre la Administración Local en la Comunidad, ver FeRnÁndEZ dE GATTA SÁnchez, D., «Los problemas de la estructura municipal de Castilla y León: instrumentos y soluciones de la nueva Ley de Régimen Local», El Consultor, n. ${ }^{\circ}$ 19/1999; «La estructura municipal de Castilla y León: Incidencia de la Legislación sobre Régimen Local, Urbanismo y Ordenación del Territorio», REAL, n. ${ }^{\circ}$ 291/2003, en Homenaje al Prof. Dr. D. Sebastián MARTíN-RETORTILLO BAQUER; «Las Mancomunidades Municipales en Castilla y León: evolución, régimen vigente y perspectivas futuras», REALA, n. ${ }^{\circ} 296-297$, septiembre de 2004-abril de 2005; «El Acuerdo de Pacto Local de Castilla y León de 2005: Un instrumento para la consolidación de las Administraciones Locales de la Comunidad», X Congreso de Economía de Castilla y León [Valladolid, 23 y 24 de noviembre de 2006], Comunicaciones, Vol. I, Ed. Consejería de Economía y Empleo (JCyL), Valladolid, 2006, y «Fórmulas asociativas para la mejor prestación de los servicios públicos: Mancomunidades de Municipios y Consorcios», Revista de Estudios Locales (COSITAL), Número Monográfico sobre «Los Servicios Públicos Locales», julio de 2007.

Sobre la situación actual, ver Sosa WAGNER, F. (Coord.) y otros, «Pacto Local», Revista Jurídica de Castilla y León, Número Extraordinario, octubre de 2006.

La normativa puede verse en JUNTA DE CASTILLA Y LEOn, «Recopilación normativa de la Comunidad de Castilla y León», 2 Tomos, Ed. JCyL, Valladolid, 2007. 
EL RÉGIMEN DE LAS COMPETENCIAS Y DE LOS LÍMITES DE LOS DISTRITOS...

tidos Políticos mayoritarios y teniendo en cuenta el trabajo de la Comisión No Permanente de las Cortes de Castilla y León creada para estudiar la reforma (BOCCYL, n. ${ }^{\circ} 283$, de 31 de julio de 2006), se debatió y aprobó la Propuesta de Reforma del Estatuto de Autonomía de Castilla y León (PREA 1-VII, BOCCYL, n. ${ }^{\circ} 328$, de 15 de diciembre de 2006); texto que fue remitido a las Cortes Generales para su tramitación parlamentaria (BOCG-Congreso de los Diputados, Serie $\mathrm{B}$, n. $^{\circ} 268$, de 15 de diciembre de 2006) y que, después de los trámites parlamentarias, fue aprobado definitivamente por el Senado el día 21 de noviembre de 2007 (BOCG-Senado, Serie III B, n. ${ }^{\circ} 26$-e, de 23 de noviembre de 2007), y que se ha convertido en la Ley Orgánica 14/2007, de 30 de noviembre, de Reforma del Estatuto de Autonomía de Castilla y León (BOE n. ${ }^{\circ}$ 288, de 1 de diciembre).

Este nuevo Estatuto de Autonomía introduce innovaciones de interés, respetando plenamente lo establecido por la Constitución Española, como es visible en su art. 1 y en el resto del mismo (destacando además que en su importante Exposición de Motivos se contiene una excelente lección sobre la historia de España, y sobre el consolidado carácter histórico de esta Comunidad). Respecto al ámbito local y municipal, se incluye el Título III (arts. 43 a 56), relativo a la Organización Territorial, que afianza aún más los Municipios y las Provincias en Castilla y León, en particular respecto a sus competencias (en el marco de la Legislación Básica y de la propia normativa autonómica); siendo destacable, además, entre otras cuestiones, la regulación de las Comarcas, la previsión general de los procesos de transferencia y delegación de competencias, la creación del Consejo de Cooperación Local, el reconocimiento del derecho de asociación de las Entidades Locales y la regulación de las Haciendas Locales. Respecto a los Municipios, el art. 44 reafirma su condición como entidad territorial básica de la Comunidad y como institución de participación más directa de los ciudadanos en los asuntos públicos, y se reconoce su personalidad jurídica propia y plena autonomía en el ámbito de sus competencias y en la defensa de los intereses locales que representa. Asimismo, se prevé que su gobierno, representación y administración corresponde al Ayuntamiento. Respecto a sus competencias, el art. 45 establece que los Municipios tienen las propias que se establecen por la Legislación Básica y la de la Comunidad; competencias que se ejercen con plena autonomía. Además, el mismo precepto establece que las competencias de las Entidades Locales corresponderán a los Municipios, salvo que la Ley que reconozca tales competencias las asigne a otras Entidades Locales. En este mismo marco, también se reconoce que los Municipios tienen capacidad para ejercer su iniciativa en toda materia de interés local que no esté expresamente excluida de su competencia o atribuida a otras Administraciones por la Legislación del Estado o de la Comunidad Autónoma. Además, se prevé la elaboración por la Comunidad, en el marco de la Legislación Básica y del propio Estatuto, de una ley de regulación del gobierno y la administración local; contemplando las Entidades Locales Menores, las Comarcas, Áreas Metropolitanas (que se crearán mediante ley específica), Mancomunidades, Consorcios y otras Agrupaciones de carácter funcional y fines específicos, y preservando las formas tradicionales de organización local. 
En base al Estatuto original, e incluso con anterioridad a la reforma estatutaria de 1999 y por supuesto a la de 2007, se aprobó la Ley 1/1998, de 4 de junio, de Régimen Local de Castilla y León (BOCYL n. ${ }^{\circ}$ 109, de 11 de junio; corrección de errores en BOCYL del 29 de julio).

La Ley se inicia con una Exposición de Motivos bastante clara y realista sobre la compleja estructura municipal de la Comunidad, al ser muy reveladora de la preocupante situación local. Por lo que el texto es más una Ley reguladora de todo el régimen local que un texto más regulador del ámbito municipal (cuya organización complementaria se deja a lo establecido por la Legislación Básica y a la normativa de los propios Municipios). Así, reconoce a los Municipios su condición de entidad local básica de Castilla y León (art. 2), y menciona las Provincias (art. 5) y las Comarcas (art. 6). A continuación, la Ley aborda la creación y supresión de Municipios (arts. 9 a 18), dejando suficiente margen a la Administración Regional para emprender una adecuada política de reestructuración municipal. Seguidamente, la Ley, después de referirse a las competencias municipales, se detiene en la regulación de los servicios mínimos municipales (arts. 20 a 23). Además, la Ley de Régimen Local regula otros Entes Locales, como las Mancomunidades Municipales (arts. 29 a 41), las Comunidades de Villa y Tierra (arts. 42 a 44), las Entidades Metropolitanas (arts. 45 a 47), los Consorcios (art. 48) y con especial minuciosidad las Entidades Locales Menores (Título VII, arts. 49 a 71). Para terminar, la Ley regula las relaciones entre la Comunidad Autónoma y las Entidades Locales (arts. 81 a 110), regulando el régimen de las delegaciones y transferencias a otros Entes Locales y el sistema organizativo correspondiente, junto a técnicas de coordinación.

Debido, quizás, a la peculiar y problemática estructura municipal y poblacional de la Comunidad, la Ley de Régimen Local presta más atención a la misma y a los instrumentos para su gestión, que a otras cuestiones como las técnicas de desconcentración y su plasmación en la creación de Distritos, remitiendo dicha cuestión a la propia normativa municipal, de acuerdo con la legislación nacional. Así, el Reglamento Orgánico del Ayuntamiento de Valladolid, de 2 de noviembre de 2004 (BOP de 13 de diciembre de 2004), incluye entre las competencias del Pleno municipal la relativa a «la división del Municipio en distritos, y la determinación y regulación de los órganos de los distritos y de las competencias de sus órganos representativos y participativos, sin perjuicio de las atribuciones del Alcalde para determinar la organización y las competencias de su administración ejecutiva» (art. 42); debiéndose resaltar que Valladolid es el único Municipio en la Comunidad al que se le aplica el régimen de los de gran población.

\section{9) Comunidad Autónoma de Cataluña}

El anterior Estatuto de Autonomía, aprobado por Ley Orgánica 4/1979, de 18 de diciembre (BOE del 22), estructuraba el territorio de la Comunidad en 
EL RÉGIMEN DE LAS COMPETENCIAS Y DE LOS LÍMITES DE LOS DISTRITOS...

Municipios y Comarcas, previendo asimismo la posibilidad de crear demarcaciones supracomarcales, y agrupaciones basadas en hechos urbanísticos y metropolitanos y otras de carácter funcional y fines específicos; remitiéndose a una Ley la regulación de ésa organización territorial (art. 5) ${ }^{26}$.

En base a tal disposición se dictó la Ley 8/1987, de 15 de abril, Municipal y de Régimen Local (DOGC del 27), modificada en varias ocasiones posteriormente, y sobre el texto de esta Ley se aprobó más tarde la Ley 22/1998, de 30 de diciembre, de la Carta Municipal de Barcelona (DOGC de 8 de enero) ${ }^{27}$, modificada en 2006; la cual, según su Exposición de Motivos, nace con el deseo de dar respuesta a la demanda de mayor proximidad que hacen las grandes ciudades de Europa, de dar prioridad al nivel de administración más cercano y de construir la Europa de la subsidiariedad, en base a todo lo cual la finalidad del texto es establecer el régimen jurídico especial para el Municipio de Barcelona (art. 1). En relación con la organización municipal, el art. 8 establece que el Gobierno municipal actúa de acuerdo con los principios de eficacia, jerarquía, descentralización, desconcentración y coordinación, y que deben ser criterios esenciales de su organización diferenciar las funciones deliberantes de ordenación, programación y control de las ejecutivas de gobierno y administración, y desarrollar la descentralización y desconcentración territorial y fomentar la participación ciudadana.

Respecto a los Distritos ${ }^{28}$, la Exposición de Motivos de la Ley señala que «...la Carta refuerza la voluntad descentralizadora de Barcelona dotando los

\footnotetext{
26 ENTRENa Cuesta, R., «Organización Territorial. Comentario al artículo 5», y FerRET Y JACAS, J., «Régimen Local», en VARIOS AUTORES, «Comentarios sobre el Estatuto de Autonomía de Cataluña», Vol. I, Ed. Instituto de Estudios Autonómicos, Barcelona, 1990; MIR Y BAGO, J., «La organización política e institucional de la Administración Local en la Cataluña rural», Revista catalana de Derecho Público, n. ${ }^{\circ}$ 13/1991; CUCHILLO FOIX, M., «La organización territorial de Cataluña: opciones y niveles de concreción», Revista catalana de Derecho Público, n. ${ }^{\circ}$ 12/1990.
}

27 En relación con el régimen especial de la ciudad de Barcelona, véanse GALÁN GALÁn, A., «La Carta Municipal de Barcelona», Diario La Ley, Tomo I/2000, y «La Carta Municipal de Barcelona y el Ordenamiento Local. El régimen especial del Municipio de Barcelona», Ed. Marcial Pons-Fundación Carlos Pi y Suñer, Madrid-Barcelona, 2001; JIMÉNEZ ASENSIO, R., «El régimen especial del Municipio de Barcelona: evolución y contenido actual», en TRONCOSO REIGADA, A. (Dir.), y otros, «Comentarios a la Ley de Capitalidad y de Régimen Especial de Madrid. Ley 22/2006, de 4 de julio», Ed. Thomson-Aranzadi, Cizur Menor (Navarra), 2007, págs. 875-912; IGLESIAS MARTín, A., «La Ley 22/1998, de 22 de diciembre, de la Generalidad de Cataluña, por la que se aprueba la Carta Municipal de Barcelona, como manifestación del principio de autonomía local y como signo positivo de democracia local», El Consultor, n. ${ }^{\circ}$ 9/2001, págs. 1485 y ss.; FonT Y Llovet, T., y JimÉnEZ ASENSIO, R. (Coords.), y otros, «Carta Municipal de Barcelona. Diez estudios», Ed. Marcial Pons-Fund. Pi y Suñer, Madrid-Barcelona, 2007, y especialmente, en la materia estudiada, JiMÉNEZ ASENSIO, R., y MALLO GÓMEZ, M., «La organización territorial en Distritos del Municipio de Barcelona», en C. Prieto Romero y A. Galán Galán (Dir.), y otros, «Los Distritos: Gobierno de Proximidad», obra citada, págs. 277-334. También Betancor A. (Dir.), y otros, «Comentarios al régimen municipal especial de Barcelona», Ed. Thomson-Civitas, Cizur Menor (Navarra), 2008.

28 JimÉnEZ ASENSIO, R., y MALlo GóMEZ, M., «La organización territorial en Distritos del Municipio de Barcelona», obra citada, págs. 294-298, mantienen el carácter obligatorio de los mismos, derivándolo de la Carta; cuestión no muy clara, aunque puede justificarse por su inclusión entre los órganos de gobierno de la ciudad (art. 9), si bien dicha interpretación colisiona con la claridad del art. 21 (que remite al Consejo Muni- 
distritos de la ciudad de una fuerte personalidad, con un amplio nivel de autogobierno. Al servicio de esta descentralización, la Carta anuncia,.../..., un nuevo sistema de composición y elección de los Consejos de Distrito, y abre las puertas para que dicha elección tenga lugar en el mismo ámbito territorial y para que se reduzcan los requerimientos de edad en el peldaño inicial de la participación política...». Su trascendencia se refleja claramente en el art. 9, al establecer que el gobierno del Municipio de Barcelona corresponde, entre otros órganos, a los Presidentes y Concejales de Distrito, si procede, y los Consejos de Distrito. Regulándose los mismos en el Título II de la Ley (arts. 20 a 25), que los concibe como órganos territoriales para la desconcentración de la gestión y descentralización de la participación ciudadana, y para la aplicación de una política municipal orientada a la corrección de los desequilibrios y la representación de los intereses de los distintos barrios y zonas del municipio; cuya actuación debe ajustarse a los principios de unidad de gobierno, eficacia, coordinación y solidaridad. El establecimiento de Distritos corresponde al Consejo Municipal (que se extiende a todo el término municipal, aunque transitoriamente pueda hacerse una excepción para alguna zona debido a circunstancias especiales que aconsejen la intervención directa de los Órganos centrales), así como establecer su número y límites territoriales, organización y funciones. Desde el punto de vista de asegurar la prestación de sus funciones materiales (aunque también debe tenerse en cuenta que, aún siendo importante tal porcentaje, lo más adecuado hubiera sido vincular la financiación real a las funciones a prestar por los Distritos, previendo así su evolución), la Ley obliga a que el presupuesto municipal garantice que cada año el $15 \%$ de sus recursos ordinarios, como mínimo, sean gestionados por los Distritos.

En cuanto a la organización de los Distritos ${ }^{29}$ se prevé que su Presidente sea nombrado, y separado, de entre los Concejales por el Alcalde, a propuesta del Consejo de Distrito, de acuerdo con lo que disponga el Reglamento Orgánico. Corresponden al Presidente las funciones de representar al Ayuntamiento y al Distrito en su demarcación, sin perjuicio de la función representativa general del Alcalde; convocar y presidir las sesiones del Consejo de Distrito, y establecer su orden del día; someter al Consejo de Distrito el proyecto de Reglamento

cipal «el establecimiento» de los Distritos). No obstante, después de la Ley de Modernización de 2003, esta cuestión ha pasado a un segundo plano.

29 JimÉnez Asensio, R., y Mallo Gómez, M., «La organización territorial en Distritos del Municipio de Barcelona», obra citada, págs. 298-317, analizan con detalle su organización.

Quizás la cuestión más compleja y polémica es la relativa a la posible elección directa de los miembros de los Consejos de Distrito, y a su posible incidencia; cuestión no prevista aún, pero que tiene problemas de adecuación a la legalidad muy claros al no permitirse la misma por la Legislación Electoral General (como señala la STC 38/1983, de 16 de mayo) y no justificada al poder incidir en la unidad de gestión y de gobierno municipal (que, como hemos señalado, se encomienda a los Órganos representativo-democráticos, y sólo a ellos), y ser posible el intento de «crear» otro nivel administrativo más, a pesar de referirnos a unos meros órganos desconcentrados (como señala la STS de 16 de enero de 1990, AR. 7477, ya citada, referida precisamente al Ayuntamiento de Barcelona). Cuestión que estimamos no podría justificarse en la teoría de la «interiorización autonómica del régimen local», sin modificar la Constitución Española y la Legislación nacional. 
EL RÉGIMEN DE LAS COMPETENCIAS Y DE LOS LÍMITES DE LOS DISTRITOS...

Interno del propio Consejo y la propuesta del plan y programa de actuación para su aprobación; elevar a los demás Órganos municipales las propuestas del Consejo de Distrito; fomentar las relaciones del Ayuntamiento con las entidades cívicas y culturales del Distrito e informar a los administrados de la actividad municipal; impulsar los servicios y obras que se realicen en el ámbito territorial del Distrito, y dar cuenta de ello al Consejo de Distrito; convocar y presidir las sesiones del Consejo de Entidades y Asociaciones del Distrito, en los supuestos que establezcan el Reglamento Orgánico Municipal, y demás órganos consultivos, y las demás que le delegue expresamente el Alcalde.

En relación con la composición de los Consejos de Distrito y la elección de sus miembros, la misma ha de ser regulada por el Reglamento Orgánico Municipal. Correspondiéndole al mismo las funciones de aprobar, a propuesta del Presidente, el Reglamento Interno del mismo; aprobar el programa de actuación del mismo, y someterlo al Consejo Municipal; proponer a los Órganos de gobierno municipal la inclusión de asuntos en el orden del día, y trasladar las propuestas de acuerdo; elaborar estudios sobre las necesidades del Distrito; proponer al Órgano municipal competente la aprobación de instrumentos de ordenación urbanística que afecten su ámbito territorial; emitir informe preceptivo en la aprobación del Programa de Actuación Municipal, de los instrumentos de ordenación urbanística que afecten a su ámbito territorial, de los proyectos de equipamientos del Distrito, de concesión de viviendas en el mismo ámbito territorial, de desarrollo del proceso de descentralización y participación, de estudio de las peticiones e iniciativas individuales y colectivas de los vecinos, a efectos de trasladarlas, con el correspondiente informe, a los Órganos municipales competentes, y de los presupuestos municipales; y el control y fiscalización de los órganos cuando el ámbito territorial de actuación sea el del Distrito.

Además, la Ley prevé que el Alcalde ha de delegar en un Concejal, que recibe la denominación de Concejal de Distrito, sus atribuciones para que puedan ser ejercidas en el ámbito territorial del mismo, sin perjuicio de las correspondientes a sus Órganos de gobierno. Dicho Concejal tendrá, como mínimo, las funciones de dirigir la administración del Distrito y ejercer la dirección del personal adscrito, inspeccionar los servicios y obras, disponer gastos dentro de los límites de su competencia, autorizar y ordenar el pago y rendir cuentas, elaborar la plantilla orgánica del Distrito y definir la organización de sus servicios, velar por la protección ciudadana en el Distrito y adoptar, en caso de emergencia, las medidas necesarias de carácter urgente para la seguridad de las personas y bienes, de las que ha de dar cuenta inmediata a la Alcaldía, y establecer la coordinación necesaria, de acuerdo con las directrices establecidas por la Junta Local de Seguridad, asegurar la relación constante del Distrito con los distintos ámbitos de la Administración Municipal, y las demás que le delegue el Alcalde.

En cuanto al régimen jurídico de los Distritos, se prevé que los acuerdos de sus Órganos colegiados han de adoptarse por mayoría simple de sus miembros 
con alguna excepción. Además, se establece que los actos de estos mismos que sean definitivos o que, incluso siendo de trámite, decidan directamente o indirectamente el fondo del asunto de forma que pongan fin al procedimiento o bien suspendan su continuación, o que causen indefensión, pueden ser recurridos ante el Alcalde; reafirmando así las funciones materiales y de gestión administrativa de los Distritos (las cuales, no obstante, no se reflejan claramente al relacionar sus funciones), y se potencian las relativas del Alcalde para dirigir la Administración municipal; previsión normativa, no obstante, con claros problemas constitucionales respecto a la competencia sobre el procedimiento administrativo común (art. 149-1. ${ }^{\circ}, 18{ }^{\text {a}}-\mathrm{CE}$ ), y que ha provocado su necesaria solución normativa en la Ley 1/2006, de 13 de marzo (BOE del 14), como veremos inmediatamente, si bien pueden plantearse dudas sobre la justificación de este régimen especial respecto al régimen general en la materia.

Por otra parte, al regular las formas de organización para la gestión de los servicios y actividades municipales, los arts. 45 y 46 de la Ley incluyen, entre las formas de gestión directa, la gestión desconcentrada, previéndose que el Consejo Municipal, el Alcalde y la Comisión de Gobierno puedan desconcentrar (y descentralizar, dice) las respectivas competencias a otros Órganos municipales o a los Concejales; considerando los centros gestores como órganos con autonomía funcional y presupuestaria, sin personalidad jurídica, y cuyas características son la homogeneidad o afinidad del producto, la autosuficiencia para la producción de resultados y la gestión por objetivos.

Posteriormente, la Ley Municipal y de Régimen Local citada ha sido objeto de diversas modificaciones, cuestión que obligó a adoptar el Decreto Legislativo $2 / 2003$, de 28 de abril, por el que se aprueba el Texto Refundido de la Ley Municipal y de Régimen Local (DOGC de 20 de mayo), modificado en 2006. Esta Ley considera que los Municipios y las Comarcas son los Entes locales en que se organiza territorialmente Cataluña; reconociendo la existencia de otros, y considerando que Municipios, Comarcas y Provincias tienen naturaleza territorial y autonomía para la gestión de sus propios intereses (arts. 1 a 3). Además, entre los principios de organización de los Entes Locales se prevé que las Entidades Locales sirven con objetividad a los intereses públicos encomendados y actúan de acuerdo con los principios de eficacia, descentralización, desconcentración, coordinación y participación, con pleno sometimiento a la Ley y al Derecho (art. 7). Respecto a los Municipios, el art. 46 de la Ley establece que el Municipio es la entidad básica de la organización territorial y el elemento primario de participación ciudadana en los asuntos públicos; por lo que las Leyes garantizan la participación del mismo en todos los asuntos públicos que afectan directamente a sus intereses. Además, la Ley establece que el Municipio disfruta de autonomía, tiene personalidad jurídica y plena capacidad para el ejercicio de las funciones públicas encomendadas, para representar los intereses de la colectividad y para gestionar los servicios públicos de los que son titulares. La organización municipal incluye, como ya sabemos, la organización 
necesaria (Alcalde, Tenientes de Alcalde, Pleno, etc.) y otros complementarios, entre los que menciona los de participación ciudadana y otros que pueda crear el propio Municipio, de acuerdo con los principios de eficacia, economía organizativa y participación ciudadana (arts. 48 y 49).

En relación con la organización del Ayuntamiento, el art. 61 prevé que el Pleno Municipal pueda crear órganos territoriales de gestión desconcentrada con el fin de facilitar la participación ciudadana en la gestión de los asuntos municipales. Estos órganos se integran por Concejales y representantes de vecinos y de las asociaciones ciudadanas, con el límite de que el número de Concejales no puede ser superior a un tercio del total, vocales que se designan aplicando el principio de proporcionalidad en relación con los resultados de las Elecciones Locales; respecto a la participación de las asociaciones ciudadanas, se aplica el criterio de proporcionalidad en relación con su implantación efectiva. Estos órganos están presididos por el Concejal en quien delegue el Alcalde, debiendo corresponder el nombramiento en un miembro de la lista más votada en el ámbito territorial correspondiente. Asimismo, también por acuerdo del Pleno municipal, pueden crearse Órganos de participación sectorial en relación con los ámbitos de actuación pública municipal que por su naturaleza lo permitan, con la finalidad de integrar la participación de los ciudadanos y de sus asociaciones en los asuntos municipales; estando presididos también por los Concejales en quien delegue el Alcalde (art. 62).

Corresponden a estos Órganos de participación, en relación con el territorio o el sector material correspondiente, las funciones de formular propuestas para resolver los problemas administrativos que les afectan, emitir informes a iniciativa propia o del Ayuntamiento, sobre materias de competencia municipal, emitir y formular propuestas y sugerencias en relación con el funcionamiento de los servicios y los Organismos públicos municipales y otras de naturaleza análoga que determine el acuerdo de creación de los mismos (art. 63).

Los órganos territoriales de participación pueden ejercer por delegación funciones deliberativas y ejecutivas en las materias relativas a la gestión y la utilización de los servicios y los bienes destinados a actividades sanitarias, asistenciales, culturales, deportivas y de recreo cuando su naturaleza permita la gestión desconcentrada y no afecte a los intereses generales del Municipio; delegación que puede ampliarse a otras actividades, siempre que concurran las condiciones anteriores.

En relación con las funciones y competencias de estos Órganos desconcentrados, la Ley precisa el límite establecido en la Legislación Básica para garantizar el principio de unidad de gobierno y de gestión del Municipio, al prescribirse que el ejercicio de las facultades de gestión y ejecución corresponde, en todo caso, al Concejal presidente, de acuerdo con las decisiones adoptadas por el Órgano de participación; que han de establecerse los sistemas de revisión y control de los actos y los acuerdos adoptados por los Órganos de participación; que los 
Órganos desconcentrados tienen que ejercer sus funciones de acuerdo con los programas y las directrices establecidos por el Pleno municipal, y que los actos de estos Órganos de participación territorial pueden impugnarse ante al órgano correspondiente del Ayuntamiento (art. 64). Siendo, así quizás, la Ley autonómica que con mayor claridad establece el contenido positivo de tal límite.

Además, la Ley permite que los núcleos separados de población se constituyan en Órganos de participación, con algunas matizaciones (art. 65).

Finalmente, entre otras cuestiones destacables de la Ley, se asume el régimen especial de la Ley de la Carta Municipal de Barcelona (art. 78), ya mencionado.

En este mismo contexto, como ya sabemos, el régimen especial del Municipio de Barcelona se reguló en 1960 y 1974; disposiciones que se mantuvieron en vigor por la Disp. Ad. 6. ${ }^{\text {a }}$-LBRL (que, como sabemos, se refiere también a la ciudad de Madrid), si bien se permite su actualización mediante Ley autonómica, con ciertas particularidades (cuestión que, como ya sabemos, lleva a cabo la Ley de la Carta Municipal de Barcelona de 1998). Por otra parte, la misma LBRL se modifica mediante la Ley de Modernización de 2003 para regular los Municipios de Gran Población; régimen no aplicable a la ciudad de Barcelona hasta la aprobación de su régimen especial (DT-4. ${ }^{a}$ de la Ley de Modernización). Además, el art. 161 de la Ley de Haciendas Locales (Texto Articulado aprobado mediante Real Decreto Legislativo 2/2004, de 5 de marzo, BOE del 9) prevé también un régimen financiero especial para el Municipio de Barcelona. Finalmente, por una parte, el Senado adoptó el acuerdo de 19 de febrero de 2002 instando al Gobierno de la Nación a la presentación de un Proyecto de Ley para otorgar al Ayuntamiento de Barcelona las capacidades y competencias que se recogen en la Carta Municipal, y, por otra parte, el Congreso de los Diputados, el 18 de marzo de 2003, adoptó una Proposición No de Ley sobre las grandes ciudades, las ciudades y sus áreas de influencia urbana, en el que insiste en el cumplimiento del acuerdo del Senado.

En base a estos textos, se aprobó la Ley 1/2006, de 13 de marzo, por la que se regula el Régimen Especial del Municipio de Barcelona (BOE del 14), derogando por ello las normas en las que se basaba hasta ahora este régimen especial (Disp. Derogatoria Única de esta Ley); texto que únicamente contiene disposiciones materiales, y no organizativas (salvo las precisiones sobre la aplicación del nuevo régimen de los Municipios de Gran Población y algunas otras cuestiones de carácter indirecto). En este sentido, se precisa que el régimen especial del Municipio de Barcelona se integra por esta Ley y por la ya citada Ley de la Carta Municipal de 1998 (art. 1), sobre la base de garantizar la autonomía municipal, de reconocer al Ayuntamiento una cláusula general de competencias y reafirmar y regular su régimen financiero especial (arts. 1 a 4). Así, el texto de la Ley se articula sobre dos grandes partes: en la primera se regulan las competencias del Ayuntamiento de Barcelona (en materia de infraestructu- 
ras, dominio público y bienes inmuebles, telecomunicaciones, etc.) y en la segunda parte el régimen financiero especial (regulando los recursos tributarios y de otra clase, así como los aspectos de planificación económica, presupuestarios y sobre gasto público, incluyendo su control). Además, debe tenerse en cuenta que, para solucionar los problemas competenciales señalados del art. 25

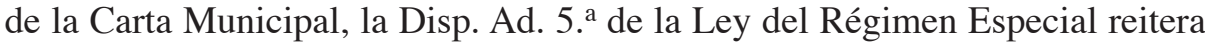
que serán recurribles en alzada ante el Alcalde las resoluciones y los actos de trámite emanados de los Órganos de Distrito que decidan directa o indirectamente el fondo del asunto, determinen la imposibilidad de continuar el procedimiento, produzcan indefensión o perjuicio irreparable a derechos e intereses legítimos (aunque ha de destacarse que este reconocimiento se hace ahora en una Ley nacional, con lo que, además de solucionar el problema competencial, reafirma las competencias de los Distritos).

Finalmente, por ahora, la Ley Orgánica 6/2006, de 19 de julio, aprueba el nuevo Estatuto de Autonomía (BOE del 20), que en la actualidad se encuentra recurrido ante el Tribunal Constitucional.

El nuevo texto, en el que es bien visible la denominada corriente de la interiorización regional del régimen local ${ }^{30}$, prescribe que los Municipios, las denominadas «Veguerías», las Comarcas y los demás Entes locales que las Leyes determinen integran también el sistema institucional de la Generalidad, considerándolos como Entes en que la misma se organiza territorialmente, sin perjuicio de su autonomía (art.2). En el Título II, relativo a las Instituciones, se regula «El Gobierno local» (arts. 83 a 93), se reitera lo establecido en relación con que la Comunidad Autónoma estructura su organización territorial básica en Municipios y las denominadas «Veguerías». En relación con los Municipios, se

\footnotetext{
30 Sobre la negativa incidencia de las nuevas «reformas estatutarias» en el régimen local, la filosofía que subyace en los textos citados y los problemas que implican, véanse, en general, MUÑOZ MACHADO, S., «El problema de la vertebración del Estado en España (Del siglo XVIII al siglo XXI)», Ed. Iustel, Madrid, 2006; PARRA MUÑOZ, J. F., «Reivindicación de la función política de los Gobiernos Locales», Actualidad Administrativa, n. ${ }^{\circ}$ 5/2003; FonT y Llovet, T., Velasco CABAllero, F, y ORTEga Álvarez, L., «El Régimen Local en la reforma de los Estatutos de Autonomía», Ed. Centro de Estudios Políticos y Constitucionales, Madrid, 2006; ORTEGa ÁlvareZ, L., y otros, «La reforma del Estado Autonómico», Ed. Centro de Estudios Políticos y Constitucionales, Madrid, 2005; ORTEGA ÁlvareZ, L., «Reforma Constitucional y Reforma Estatutaria», Ed. Thomson-Civitas, Cizur Menor (Navarra), 2005, y «El Régimen Local y Estatutos de Autonomía», REALA, n. ${ }^{\circ}$ 300-301, enero-agosto, 2006; VELASCO CABALLERO, F., «Organización territorial y régimen local en la reforma del Estatuto de Cataluña: límites constitucionales», en VARIOS AUTORES, «Estudios sobre la reforma del Estatuto», Ed. Instituto de Estudios Autonómicos, Barcelona, 2004, «El Régimen Local en la reforma de los Estatutos de Autonomía: límites constitucionales», Congreso Internacional «Municipio Siglo XXI. Ciudadanía y Gobierno Local», Excma. Diputación Provincial de Zaragoza, 1 a 3 de diciembre de 2004 (documento original mecanografiado), y «Reforma de los Estatutos de Autonomía y Reforma de las Bases del Régimen Local», en PARAda VÁZQuez, R., y Fuentetaja PASTOR, Á. (Dirs.), y otros, «Reforma y retos de la Administración Local», Ed. Fundación Caja Rural de Toledo-Maat Gknowledge-Ed. Marcial Pons, Madrid, 2007. Asimismo, vid. FERNÁNDEZ DE GATTA SÁNCHEZ, D., «Informe sobre la incidencia de la futura Legislación Básica Local en el régimen jurídico de Castilla y León. Especial referencia al Pacto Local de Castilla y León», redactado para la Dirección General de Administración Territorial-Consejería de Presidencia y Administración Territorial (JCyL), 2006 [Contrato art. 83-LOU, clave LBIO/2006, aprobado el 5 de mayo de 2006], no publicado.
} 
consideran Entes locales básicos de la organización territorial de Cataluña y el medio esencial de participación de la comunidad local en los asuntos públicos, y se reconoce su plena capacidad de autoorganización dentro del marco de las disposiciones generales establecidas por Ley en materia de organización y funcionamiento municipal. Además se reconoce el principio de diferenciación, al prever que las Leyes que afectan al régimen jurídico, orgánico, funcional, competencial y financiero de los Municipios deben tener en cuenta necesariamente las diferentes características demográficas, geográficas, funcionales, organizativas, de dimensión y de capacidad de gestión que tienen. Por otra parte, el Estatuto reconoce el régimen especial del Municipio de Barcelona, previéndose su regulación (como ya hemos visto). Finalmente, debe tenerse en cuenta que, a efectos competenciales, corresponde a la Comunidad la competencia exclusiva en materia de régimen local que, respetando el principio de autonomía local, incluye, entre otras materias, la determinación de las competencias y de las potestades propias de los Municipios y de los demás Entes locales, en los ámbitos especificados, la determinación de los órganos de gobierno de los Entes locales creados por la Comunidad, así como el funcionamiento y régimen de adopción de acuerdos de estos órganos, y el régimen de los órganos complementarios de la organización de los Entes locales (art. 160).

\section{0) Comunidad Autónoma de Extremadura ${ }^{31}$}

Su Estatuto de Autonomía, aprobado por Ley Orgánica 1/1983, de 25 de febrero (BOE del 26), y modificado posteriormente en 1994, 1999 y 2002, señala únicamente, en esta materia, que la Comunidad podrá estructurar, mediante ley, su organización territorial en Municipios y Comarcas, de acuerdo con la Constitución (art. 2). La Comunidad no ha elaborado legislación general alguna en materia de régimen local. Únicamente, debemos señalar que mediante la Ley 8/2004, de 23 de diciembre (DOE del 30), se aplica el régimen de los Municipios de Gran Población a la ciudad de Mérida, capital de la Comunidad (en cumplimiento del art. 121-1. ${ }^{\circ}$, c-LBRL).

\section{1) Comunidad Autónoma de Galicia ${ }^{32}$}

El Estatuto de Autonomía, aprobado por Ley Orgánica 1/1981, de 6 de abril (BOE de 28 de abril), y modificado en 2002, establece que su organización territorial tendrá en cuenta la distribución de la población gallega y sus formas tradicionales de convivencia y asentamiento, y que una Ley propia regulará la organización territorial de la Comunidad (art. 2).

\footnotetext{
31 López Guerra, L, Soriano García, L. E. (Dirs.), y otros, «Comentarios al Estatuto de Autonomía de la Comunidad Autónoma de Extremadura», Ed. INAP-MAP, Madrid, 1992.

32 CARro FernándeZ-VAlmayor, J. L. (Dir.), y otros, «Comentarios al Estatuto de Autonomía de la Comunidad Autónoma de Galicia», Ed. INAP-MAP, Madrid, 1991.
} 
En base al mismo se aprobó la Ley 5/1997, de 22 de julio, de Administración Local (DOG de 5 de agosto), modificada en 1999, que se inicia declarando que la Comunidad Autónoma de Galicia se organiza en Municipios y Provincias, que ostentan la condición de Entidades Locales territoriales, a las que se garantiza la autonomía para la gestión de sus respectivos intereses (art. 1), a los que define como Entidades Locales básicas de la organización territorial de la Comunidad y cauces de participación ciudadana en los asuntos públicos locales (art. 10). En cuanto a la organización de los Municipios, el art. 59 establece que los Municipios de la Comunidad tienen la potestad de autoorganización y, por ello, podrán aprobar sus Reglamentos Orgánicos sin otro límite que el respeto a las reglas de organización municipal establecidas por la Legislación Básica y por la propia Ley. La organización municipal incluye los ya conocidos órganos necesarios, y se prevé que, entre otros, podrán complementar la organización municipal los Alcaldes de Barrio, los órganos de gestión desconcentrada y de participación ciudadana y cualquier otro órgano establecido por el Ayuntamiento y regulado por su Reglamento orgánico. Añadiendo que la creación de los órganos complementarios responderá a los principios de eficacia, economía organizativa y participación ciudadana y exigirá el cumplimiento de ciertos requisitos (determinación de su forma de integración en la organización municipal y de su dependencia jerárquica; delimitación de sus funciones y competencias; dotación de los créditos precisos para su puesta en marcha y funcionamiento).

En base a lo cual, la Ley regula los órganos territoriales para la gestión municipal desconcentrada y de participación ciudadana. En concreto, el art. 69 establece que, en los Municipios con más de 20.000 habitantes podrán constituirse, con la finalidad de facilitar la participación ciudadana en la gestión de los asuntos municipales, estos órganos; que integrarán a Concejales, en número que no podrá ser superior a la mitad del total de sus componentes, y a representantes de las asociaciones de vecinos, designados por el Alcalde a propuesta de éstas de acuerdo con su efectiva implantación. La presidencia del Órgano desconcentrado corresponderá al Concejal designado por el Alcalde, de entre los que figuren en la lista más votada en el territorio correspondiente.

Además, se prevé expresamente que estos Órganos puedan ejercer las competencias y funciones que cada Ayuntamiento les confiera, atendiendo a las características del asentamiento de la población en el término municipal y, en especial, en los sectores sanitario, asistencial, cultural, deportivo y recreativo; garantizándose, en todo caso, el principio de unidad de gobierno y gestión en el Municipio, a cuyo efecto se establecerán, en el Acuerdo de delegación, los sistemas de revisión y control de los actos y acuerdos adoptados por los Órganos de participación (art. 70).

Asimismo, por acuerdo del Pleno y en Municipios con más de 20.000 habitantes, podrán crearse Órganos de participación sectorial en relación con los ámbitos de actuación pública municipal que por su naturaleza lo permitan, con la finalidad de integrar la participación de los ciudadanos y de sus asociaciones 
en los asuntos municipales. Como en el supuesto anterior, estos Órganos están presididos por los Concejales en quienes delegue el Alcalde (art. 71).

A unos y otros, según el art. 72, les corresponderán, en relación con el territorio o el sector material correspondiente, las funciones de proponer al órgano competente fórmulas encaminadas a resolver los problemas relacionados con el ámbito de sus funciones; emitir informes, a iniciativa propia o del Ayuntamiento, sobre materias de su competencia; emitir y formular propuestas y sugerencias en relación con el funcionamiento de los servicios y organismos públicos municipales, y ejercer las demás de naturaleza semejante que determine el acuerdo de creación.

Por otra parte, en los núcleos de población separados del centro urbano y que no constituyan Entidad Local, el Alcalde podrá nombrar un Alcalde de Barrio para cada núcleo, entre los vecinos que residan en éste. Asimismo, el Alcalde también podrá nombrar Alcaldes de Barrio en las ciudades en que los servicios requieran esta designación. Los Alcaldes de Barrio han de ser vecinos de aquel en el que ejerza sus funciones. La duración del cargo estará sujeta a la del mandato del Alcalde que lo nombró, quien podrá removerle cuando lo juzgue oportuno. Finalmente, se establece que los mismos tendrán carácter de autoridad en el cumplimiento de sus funciones, en cuanto representantes del Alcalde que los nombró.

Por otra parte, más adelante se aprobó la Ley 4/2002, de 25 de junio, del Estatuto de la capitalidad de Santiago de Compostela (DOG del 24 de julio), pero sin apenas incluir referencias organizativas reseñables, pues únicamente menciona el principio de desconcentración entre los que han de cumplir los Órganos de gobierno municipal (art. 7), y deja al Reglamento Orgánico del Ayuntamiento la posibilidad de crear otros órganos, distintos de los obligatorios (art. 8).

\section{2) Comunidad Autónoma de Madrid ${ }^{33}$}

La ciudad de Madrid, como ya sabemos, gozaba, de forma directa, de un régimen especial desde la aprobación del Decreto de 11 de julio de 1963, modificado por Decreto de 22 de agosto de 1970.

33 En general, ver GARcía DE ENTERríA, E. (Dir.), y otros, «Madrid. Comunidad Autónoma Metropolitana», Ed. Instituto de Estudios Económicos, Madrid, 1983, y GóMEZ-FERRER MorANT, R. (Coord.), y otros, «Estudios sobre el Derecho de la Comunidad de Madrid», Ed. Civitas-Comunidad de Madrid, Madrid, 1987.

Sobre la situación de Madrid como capital de España y su legislación especial, vid. PRIETO ROMERO, C., «El Título I del Borrador de Anteproyecto de la Ley Especial de Madrid: la organización política y administrativa», Revista de Estudios Locales, Número Extraordinario sobre «La reforma del Gobierno Local en España», julio de 2005, págs. 113-124; FERNÁNDEZ-MIRANDA FERNÁNDEZ-MIRANDA, J., «Madrid área metropolitana, gran ciudad, capital del Estado y de su respectiva Comunidad Autónoma», Ed. Ayuntamiento de Madrid-Ed. Colex, Madrid, 2005; PARejo Alfonso, L., Bravo Rivera, J., y Prieto Romero, C. (Coords.), y otros, «Estudios sobre la Ley de Capitalidad y de Régimen Especial de Madrid», Ed. Bosch-Excmo. Ayuntamiento de Madrid, Barcelona, 2006; Morell OCAÑA, L., «Madrid. Comentarios al articulado de la Ley de Régimen Especial y de Capitalidad», Ed. Thomson-Civitas, Cizur Menor (Navarra), 2007, y TronCOSO REIGADA, A. (Dir.), y otros, «Comentarios a la Ley de Capitalidad y de Régimen Especial de Madrid. Ley 22/2006, de 4 de julio», Ed. Thomson-Aranzadi, Cizur Menor (Navarra), 2007. 
EL RÉGIMEN DE LAS COMPETENCIAS Y DE LOS LÍMITES DE LOS DISTRITOS...

Posteriormente, el Estatuto de Autonomía, aprobado por Ley Orgánica 3/1983, de 25 de febrero (BOE del 1 de marzo), y modificado después en 1994, 1998 y 2002, establece que la Comunidad se organiza territorialmente en $\mathrm{Mu}$ nicipios, y les reconoce personalidad jurídica y autonomía para la gestión de sus propios intereses (art. 3). Además, su art. 6 establece que «la villa de Madrid, por su condición de capital del Estado y sede de las instituciones generales, tendrá un régimen especial regulado por Ley, votada en Cortes. Dicha Ley determinará las relaciones entre las Instituciones estatales, autonómicas y municipales, en el ejercicio de sus respectivas competencias».

Más tarde, la Disp. Ad. 6. ${ }^{\mathrm{a}}$-LBRL mantiene el régimen especial mencionado hasta la aprobación de la Ley citada, como ya sabemos.

La Ley 2/2003, de 11 de marzo, de Administración Local (BOCM de 18), modificada en 2005 y 2007, concibe el Municipio como la Entidad local básica de la Comunidad (art. 2). En materia de organización, se establece, en el art. 28, que los Municipios, en el ejercicio de la potestad de organización, regularán la organización complementaria y completarán la necesaria, adaptándola, en su caso, a sus peculiaridades y necesidades de conformidad con los principios generales de los artículos 103-CE y 3-LRJ-PAC. Añadiendo (art. 34) que, de conformidad con lo dispuesto en el art. 28 citado, corresponde a los Reglamentos Orgánicos Municipales la creación y regulación de los órganos municipales complementarios; y estableciendo que para la gestión desconcentrada y el fomento de la participación ciudadana, los Municipios de más de 20.000 habitantes y aquellos cuyas características así lo aconsejen podrán crear Órganos colegiados integrados por vecinos y miembros de la Corporación con la composición y funciones que el Reglamento Orgánico determine, y prescribiendo que la

Sobre los Distritos y la gestión desconcentrada en Madrid, véanse PRIETO ROMERO, C., «Los Distritos en Madrid: proyecto de gestión desconcentrada», y BRIZUELA CASTILLO, L., «La organización de los Distritos de Madrid», ambos en C. Prieto Romero y A. Galán Galán (Dir.), y otros, «Los Distritos: Gobierno de Proximidad», obra citada, págs. 189-236 y págs. 237-275, respectivamente. Asimismo, vid. los siguientes trabajos de PrIETO ROMERO, C., «La organización política y administrativa», en PAREJO ALFONSO, L., BRAvo Rivera, J., y PRIETo Romero, C. (Coords.), y otros, «Estudios sobre la Ley de Capitalidad y de Régimen Especial de Madrid», obra citada, págs. 165-219; «Arts. 19 a 24. La Administración Pública del Ayuntamiento de Madrid», en Troncoso Reigada, A. (Dir.), y otros, «Comentarios a la Ley de Capitalidad y de Régimen Especial de Madrid. Ley 22/2006, de 4 de julio», obra citada, págs. 405-467; «Las recientes reformas de la Legislación local y su aplicación a las estructuras administrativas y de funcionamiento de las grandes ciudades: la gestión del cambio organizativo en el Ayuntamiento de Madrid», Cuadernos de Derecho Local, n. ${ }^{\circ}$ 9/2005; «Órganos superiores y directivos y la organización del Ayuntamiento de Madrid», Cuadernos de Derecho Local, n. ${ }^{\circ}$ 11/2006, págs. 130 y ss.; «El Ayuntamiento de Madrid: medidas de transparencia en la gestión pública», El Consultor, n. ${ }^{\circ} 7 / 2007$, págs. 1060 y ss., y «Los Distritos de Madrid: proyecto de gestión desconcentrada», Cuadernos de Derecho Local, n. ${ }^{\circ}$ 13/2007, págs. 47 y ss.; PRADO MARTínEZ, P., «La organización de los Distritos», en VARIOS AUTORES, «Jornadas sobre la Ley de Medidas para la Modernización del Gobierno Local», Ed. Ayuntamiento de Madrid, Madrid, 2004 [http://www.munimadrid.es].

Desde otro punto de vista, ver GARCía MARTín, A., «Proceso de anexión de los Municipios limítrofes a Madrid», Col. Temas Madrileños, Ed. Ayuntamiento de Madrid, Madrid, 1991, y GALÁN GALÁN, A., y TosCANO GIL, F., «Las tres dimensiones de la gran ciudad», en TRONCOSO REIGADA, A. (Dir.), y otros, «Comentarios a la Ley de Capitalidad y de Régimen Especial de Madrid. Ley 22/2006, de 4 de julio», obra citada. 
atribución a dichos Órganos de funciones ejecutivas no impedirá el control jurídico y político por el Pleno de la Corporación. Estableciendo pues un límite de población que puede parecer poco estricto, al no derivarse necesariamente de tal número de habitantes la complejidad necesaria para crear tales órganos; además se amplían las posibilidades de tal creación al remitir la misma cuando las características municipales lo aconsejen. Por otra parte, el art. 40 reafirma el régimen especial de la ciudad de Madrid.

De acuerdo con lo anterior, y teniendo en cuenta también lo establecido en la LBRL, se aprueba la Ley 22/2006, de 4 de julio, de Capitalidad y de Régimen Especial de Madrid (BOE del 5), que regula dicho régimen especial y las peculiaridades del mismo en cuanto capital del Estado y sede de las Instituciones generales ${ }^{34}$, sin perjuicio de las competencias de la Comunidad de Madrid (art. 1), y deroga las normas citadas de 1963 y 1970 (Disp. Derogatoria Única); regulando, sobre la base de la autonomía municipal, el régimen de capitalidad, el Gobierno y Administración municipales, las competencias municipales y cuestiones sobre régimen jurídico y procedimiento.

A diferencia del caso de Barcelona, la Ley de Madrid regula los aspectos organizativos en su Título II (arts. 7 a 30), en el que se regulan los Órganos ya conocidos (Pleno, Alcalde, Tenientes de Alcalde y Junta de Gobierno) y la Administración Pública del Ayuntamiento de Madrid, que se organiza y actúa, con sometimiento pleno a la Ley y al Derecho, de acuerdo con los principios de jerarquía, eficacia, descentralización funcional, desconcentración, coordinación y servicio al ciudadano (art. 19); previéndose específicamente, la regulación de los Distritos, en el art. 22, que prevé su creación por el Pleno, concibiéndose como divisiones territoriales propias, dotadas de órganos de gestión desconcentrada, para impulsar y desarrollar la participación ciudadana en la gestión de los asuntos municipales y su mejora, sin perjuicio de la unidad de gobierno y gestión de la ciudad; correspondiendo su Presidencia en todo caso a un Concejal (dejando así la regulación de su régimen completo a la potestad de autoorganización municipal, principalmente contenida en el Reglamento Orgánico de los Distritos de la ciudad de Madrid de 23 de diciembre de 2004, BOCM de 10 de enero de 2005) $)^{35}$.

\footnotetext{
34 Aragón ReYes, M., «Régimen jurídico de la capitalidad de Madrid», y PAREJO ALFONSO, L., «El Régimen de Capitalidad y el Sistema de Relaciones Interadministrativas», en PAREJO ALFONSO, L., BRAVO RIVERA, J., y PRIETO ROMERO, C. (Coords.), y otros, «Estudios sobre la Ley de Capitalidad y de Régimen Especial de Madrid», obra citada, págs. 21-36 y 97-120; FERNÁNDEZ-MIRANDA FERNÁNDEZ-MIRANDA, J., «Régimen de Capitalidad. Arts. 3 a 6», en Troncoso ReigAdA, A. (Dir.), y otros, «Comentarios a la Ley de Capitalidad y de Régimen Especial de Madrid. Ley 22/2006, de 4 de julio», obra citada, págs. 321-375, y MorELL OCAÑA, L., «Madrid. Comentarios al articulado de la Ley de Régimen Especial y de Capitalidad», obra citada, en sus comentarios a los arts. 3 a 6 , págs. 37 a 63.

35 Sobre la historia, el régimen y la organización de los Distritos de Madrid, vid en especial, por su detalle, Prieto ROMERO, C., «Los Distritos en Madrid: proyecto de gestión desconcentrada», y BRIZUELA CASTILLO, L., «La organización de los Distritos de Madrid», ambos en C. PRIETo Romero y A. Galán GaLÁN (Dir.), y otros, «Los Distritos: Gobierno de Proximidad», obra citada, págs. 189-236 y 237-275, respectivamente.
} 
EL RÉGIMEN DE LAS COMPETENCIAS Y DE LOS LÍMITES DE LOS DISTRITOS...

\section{3) Comunidad Autónoma de Murcia}

El Estatuto de Autonomía de Murcia, aprobado mediante Ley Orgánica 4/1982, de 9 de junio (BOE del 19), modificado en 1994, 1998 y 2002, señala que la Comunidad se organiza territorialmente en Municipios y Comarcas, gozando los primeros de plena personalidad jurídica y autonomía para la gestión de los intereses propios (art. 3).

En base al mismo se aprobó la Ley 6/1988, de 25 de agosto, de Régimen Local (BORM de 3 de septiembre), que reafirma que la Comunidad se organiza territorialmente en Municipios y Comarcas concibiéndolos como sus entidades básicas, y que constituyen los cauces inmediatos de participación ciudadana y vecinal (art. 1).

En materia de organización municipal, el art. 21 prevé que los mismos, en ejercicio de su autonomía organizativa y mediante el correspondiente Reglamento Orgánico, podrán establecer la estructura de su propia organización y régimen de funcionamiento; siendo posible que, en los Municipios en que así lo acuerden sus respectivos Ayuntamientos, podrán existir alguno o algunos de los órganos complementarios regulados en la misma Ley, que se aplicará con carácter supletorio respecto a los Reglamentos Orgánicos; debiendo responder la creación de los órganos complementarios a los principios de eficacia, economía organizativa y participación ciudadana. Además, el art. 22 permite que, en los Ayuntamientos que no regulen su organización complementaria, puedan existir, previo acuerdo de los mismos, uno o varios órganos complementarios, tales como Alcaldes de Barrio, de Pedanías o de Diputación, Juntas de Vecinos y Consejos Sectoriales.

Respecto a los primeros, el art. 37 establece que, en los Barrios urbanos y en las Pedanías o Diputaciones, de huerta o de campo, en que tradicionalmente se dividen los términos municipales, pueda existir un Alcalde de Barrio, de Pedanía o de Diputación, nombrado libremente por el Alcalde, de entre los vecinos de la demarcación; y que en las Pedanías recibirá el nombre tradicional de Alcalde Pedáneo. La duración del mandato de estos estará sujeta a la del Alcalde del Municipio que le nombró, quien podrá decretar su cese por el mismo procedimiento. Los Alcaldes de Barrio o Pedáneos tendrán el carácter de autoridad en el ejercicio de sus funciones municipales, como representantes del Alcalde. Las funciones que la Ley (art. 38) asigna a estos Alcaldes de Barrio o Pedáneos hacen referencia a la representación ordinaria de la Alcaldía en su ámbito territorial; la presidencia de la Junta de Vecinos y de las asambleas o reuniones de vecinos que se convoquen; la vigilancia inmediata de las obras y servicios municipales en su demarcación; informar a los vecinos sobre las normas, acuerdos y demás actuaciones municipales que les afecten; canalizar las aspiraciones de los vecinos respecto del Ayuntamiento, y cuantos otros asuntos le delegue o encargue el Alcalde.

Respecto a las segundas el art. 39 de la Ley prevé que, en cada Barrio, Pedanía o Diputación, pueda existir, como órgano territorial de gestión desconcentra- 
da, una Junta de Vecinos, cuya creación y estatuto básico se determinarán por acuerdo del Pleno, en defecto de regulación por el Reglamento Orgánico del Municipio. Dicha Junta estará integrada por el Alcalde de Barrio, de Pedanía o de Diputación y un numero de vocales que no superará un tercio del de Concejales del Ayuntamiento; cuya designación se hará de conformidad con los resultados de las Elecciones Locales, en la sección o secciones constitutivas del correspondiente Barrio, Pedanía o Diputación. En el acuerdo de creación de la Junta de Vecinos, la Ley (art. 40) prevé que se especificarán sus facultades, relativas a recibir información directa de los asuntos que les afecten, y, especialmente, ser convocadas por el Ayuntamiento a las informaciones públicas de obras, servicios y planes relativos a su ámbito territorial de gestión; elevar propuestas, iniciativas, peticiones, informes, reclamaciones o quejas a los Órganos municipales; aprobar sus propias normas de organización y funcionamiento, y el presupuesto de sus actividades, que habrán de ser ratificados por el Pleno de la Corporación; cuantas facultades les delegue el Ayuntamiento en orden a la mejor gestión de las obras y servicios municipales, así como la colaboración en la vigilancia y gestión de su ordenación urbanística, sin perjuicio de la unidad de gestión del Municipio, y facilitar la participación ciudadana en el ámbito del Barrio, la Pedanía o Diputación. La Junta de Vecinos y la asamblea o reunión de vecinos adoptarán sus acuerdos, según el art. 41, por mayoría de votos de los vecinos presentes; siendo necesario para la valida constitución de la misma, en todo caso, la presencia de su Presidente, del vocal que realice las funciones de fedatario y de otro vocal. Respecto a los aspectos financieros y materiales, el art. 42 prevé que el Ayuntamiento, dentro de sus disponibilidades, facilitará a la Junta de Vecinos los locales adecuados y los medios personales y materiales necesarios para el desarrollo de sus actividades y que el presupuesto de actividades de la misma se integrará por aportaciones municipales y voluntarias de los vecinos, así como donativos y subvenciones.

Además, el art. 43 fomenta la participación ciudadana en el ámbito municipal.

En el ámbito municipal, podemos destacar el Reglamento de Participación Ciudadana y Distritos del Ayuntamiento de Murcia, de 21 de marzo de 2005 (BORM de 16 de abril de 2005).

\section{4) Comunidad Autónoma de Navarra ${ }^{36}$}

Las peculiaridades jurídicas de la Comunidad Autónoma de Navarra, vinculadas a su historia (Leyes de 1839 y 1841) y reconocidas en la Disp. Ad. $1 .^{a}$ de

\footnotetext{
36 LOPERENA RotA, D., «Aproximación al Régimen Foral de Navarra», Ed. IVAP, Oñate, 1984; SANTAMARÍA PASTOR, J. A. (Dir.), y otros, «Comentarios al Estatuto de Autonomía de Navarra», Ed. INAP-MAP, Madrid, 1992; MARTín-Retortillo Baquer, S. (Dir.), y otros, «Derecho Público Foral de Navarra. El amejoramiento del fuero», Ed. Civitas-Gobierno de Navarra, Madrid, 1992, y RAZQuín LiZARRAGA, M. M., y LARUMBE BIURRUN, P.M. (Dirs.), y otros, «La Administración Local de Navarra», Gobierno de Navarra y Ed. Aranzadi, Pamplona, 1987.
} 
EL RÉGIMEN DE LAS COMPETENCIAS Y DE LOS LÍMITES DE LOS DISTRITOS...

la Constitución Española, han traído consigo el reconocimiento de una amplia competencia en materia de régimen local, la cual se refleja en el art. 46 del Estatuto de Autonomía, aprobado por Ley Orgánica 13/1982, de 10 de agosto (BOE del 16), y modificado en 2001; precepto que reconoce la autonomía municipal.

De acuerdo con los arts. 18 y 46 del Estatuto de Autonomía, se aprobó la Ley Foral 6/1990, de 2 de julio, de Administración Local (BON del 13), modificada varias veces; mediante la cual la Comunidad organiza su Administración Local, de acuerdo con los principios de autonomía, participación, desconcentración, eficacia y coordinación en la gestión de los intereses públicos para la consecución por ésta de la confianza de los ciudadanos; afirmando que los Municipios son las Entidades locales básicas en que se organiza territorialmente la misma Comunidad (arts. 1 y 2). Respecto a la organización de los Municipios de Navarra, así como a la formación de sus Órganos de gobierno y administración, la Ley remite a las disposiciones aplicables en el resto del Estado (art. 8). Prescribiendo, asimismo, que el régimen de organización aplicable al Municipio de Pamplona será el previsto en el Título X-LBRL, con las peculiaridades que se derivan de la propia Ley Foral (art. 9 bis).

Respecto a esto último, se ha aprobado Ley Foral 16/1997, de 2 de diciembre, por la que se establece la «Carta de Capitalidad de la ciudad de Pamplona», dotando al Ayuntamiento de un complemento singular a su régimen ordinario de financiación (BON del 12), pero de carácter exclusivamente económicofinanciero.

\section{5) Comunidad Autónoma de La Rioja ${ }^{37}$}

El Estatuto de Autonomía, aprobado por Ley Orgánica 3/1982, de 9 de junio (BOE del 19), y modificado en 1994, 1999 y 2002, prevé que la Comunidad estructura su organización territorial en Municipios (art. 5).

De acuerdo con lo dispuesto en el Estatuto, la Ley 1/2003, de 3 de marzo, de la Administración Local (BOR del 11), establece que la Comunidad se organiza territorialmente en Municipios y en las Comarcas que se constituyan; concibiendo el Municipio como la entidad local básica de La Rioja, y dotado de personalidad jurídica plena y goza de autonomía para la gestión de sus intereses (art. 2). Además, entre los principios de actuación de las Administraciones Públicas sobre el territorio, se menciona el relativo a la máxima proximidad de la gestión a los ciudadanos (art. 4).

Respecto a la organización municipal, el art. 28 establece que podrán existir aquellos otros órganos complementarios que determine el Ayuntamiento en

37 Chueca Rodríguez, R. (Dir.), y otros, «Derecho Público de la Comunidad Autónoma de La Rioja», Ed. Thomson-Aranzadi, Cizur Menor (Navarra), 2007. 
su Reglamento Orgánico; texto, de creación facultativa de los Ayuntamientos, que, en ejercicio de la potestad de autoorganización, regulará su constitución y funcionamiento, adaptándola a las peculiaridades y necesidades del respectivo Ayuntamiento, sin otro límite que el respeto a la Legislación Básica y a los principios que, con el carácter de mínimos, establece la propia Ley.

En este sentido, el artículo 32 de la Ley regula las Juntas de Distrito o de Barrio; que pueden ser creadas, en los Municipios de más de 5.000 habitantes, por el Pleno como órganos territoriales de gestión desconcentrada con el fin de facilitar la participación ciudadana en la gestión municipal, en los términos previstos en su Reglamento Orgánico o de Participación. No obstante, en ausencia de regulación específica, dichas Juntas estarán integradas por Concejales y representantes de las Asociaciones vecinales, prescribiéndose que los Concejales serán designados por el Alcalde, a propuesta de los Grupos políticos, como también los representantes de las asociaciones vecinales, en esta caso a propuesta de las mismas y de acuerdo con su efectiva implantación; siendo presidida la Junta por el Concejal en quien el Alcalde delegue.

Por otra parte, el artículo 33 regula las Juntas de Vecinos, que podrán constituirse como órganos territoriales de participación, en los núcleos de población separados de la capitalidad del Municipio que no tengan la condición de Entidad Local Menor. Respecto a su composición, se establece que cuando el núcleo de población tenga menos de cien habitantes, la Junta de Vecinos estará integrada por la totalidad de los electores, presidiéndola el Concejal que a tal efecto designe el Alcalde, y que cuando el núcleo de población tenga cien o más habitantes, la Junta de Vecinos se formará por representación de acuerdo con los criterios establecidos para las Entidades Locales Menores, presidiéndolas también el Concejal que a tal efecto designe el Alcalde. En ambos casos, su funcionamiento se ajustará a lo previsto en el Reglamento Orgánico municipal y, en su defecto, en las normas supletorias que apruebe la Comunidad. En todo caso, se prescribe que los acuerdos y resoluciones adoptados por la Junta de Vecinos y su Presidente serán susceptibles de impugnación mediante recurso de alzada ante el Alcalde. La Junta de Vecinos podrá ejercer las siguientes funciones de consulta, propuesta e informe en relación con todas las actuaciones municipales que afecten específicamente al núcleo de población, y de gestión y administración en relación con los equipamientos públicos locales y la organización de actividades festivas, culturales y sociales. Para el cumplimiento de sus funciones se prevé que el Ayuntamiento asignará a la Junta de Vecinos los recursos económicos adecuados al efecto.

Por otra parte, la Ley 1/2004, de 16 de febrero (BOR del 19), aplica al Municipio de Logroño el régimen de organización de los Municipios de Gran Población. 
EL RÉGIMEN DE LAS COMPETENCIAS Y DE LOS LÍMITES DE LOS DISTRITOS...

\section{6) Comunidad Autónoma del País Vasco ${ }^{38}$}

El Estatuto de Autonomía, aprobado mediante Ley Orgánica 3/1979, de 18 de diciembre (BOE del 22), no incluye referencias específicas sobre la organización de los Municipios, salvo las relativas a los aspectos competenciales y la incidencia de la estructuración de la Comunidad en los Territorios Históricos (art. 37); ni tiene regulación regional alguna en la materia.

\section{7) Comunidad Autónoma Valenciana}

El Estatuto de Autonomía, aprobado por Ley Orgánica 5/1982, de 1 de julio (BOE del 10), modificado en 1991, 1994 y especialmente por Ley Orgánica 1/2006, de 10 de abril (BOE del 11), sobre la que debe tenerse en cuenta la STC 249/2007, de 13 de diciembre, establece en su art. 63 que las Entidades Locales comprendidas en el territorio de la Comunidad administran con autonomía los asuntos propios y, respecto a los Municipios, el art. 64 prevé a elaboración por la Comunidad de una Ley de Régimen Local y que las Cortes Valencianas impulsarán la autonomía local, entre otras cuestiones.

Por otra parte, diversas Leyes autonómicas han aplicado el régimen de organización de los Municipios de Gran Población a Elche (Ley 1/2005, de 27 de mayo, DOGV de 2 de junio), Castellón (Ley 12/2005, de 22 de diciembre, DOGV del 30) y Torrevieja (Ley 8/2006, de 14 de julio, DOGV del 17).

\section{8) Ciudades Autónomas de Ceuta y Melilla}

Sus Estatutos de Autonomía aprobados por Ley Orgánica 1/1995, de 13 de marzo (BOE del 14), para Ceuta, y Ley Orgánica 2/1995, de 13 de marzo (BOE del 14), para Melilla, no incluyen referencias directas a la materia; únicamente se señala, en el art. 25 de ambos textos, que las dos Ciudades Autónomas ejercerán todas las competencias que la Legislación nacional atribuye a los Ayuntamientos (y a las Diputaciones Provinciales).

38 Zurita Laguna, Á., «Los Distritos de la villa de Bilbao», en C. Prieto Romero y A. Galán Galán (Dir.), y otros, «Los Distritos: Gobierno de Proximidad», obra citada, págs. 443-465. 